\title{
Why the Testamentary Doctrine of Undue Influence Should Be Abolished
}

\author{
Carla Spivack* $^{*}$
}

\section{INTRODUCTION}

Many scholars have criticized the doctrine of undue influence in wills, but none so far has called for its abolition. This call is long overdue. Three objections to the doctrine of undue influence-historical, doctrinal, and psychological—warrant its abandonment.

As a matter of history, courts shifted the doctrine from the realm of chancery to that of law, ${ }^{1}$ in the process unintentionally promoting its distortion and misuse. ${ }^{2}$ As a matter of doctrine, undue influence fails to meet any standard of clarity, fairness, or predictability that a legal doctrine should satisfy. ${ }^{3}$ Finally, as a matter of psychology, undue influence relies on false notions of selfhood and autonomy. ${ }^{4}$ These three inadequacies - the distortions resulting from its transposition from equity to law, the lack of fairness or doctrinal clarity attending its use, and the shaky and questionable psychological foundations on which it rests-

\footnotetext{
* Associate Professor of Law, Oklahoma City University School of Law, B.A. Princeton University, J.D. New York University School of Law, Ph.D. Boston College. My deepest thanks to Richard B. Bernstein, Paula J. Dalley, Michael Grynberg, Eric Bradford Hermanson, William P. LaPiana, Arthur G. LeFrancois, Melanie B. Leslie, Ray D. Madoff, Michael P. O’Shea, Frederic S. Schwartz, Robert H. Sitkoff, Joshua C. Tate, and to the Oklahoma City University Faculty Colloquium, the American College of Trusts and Estates, and the Florida State Faculty Colloquium, in particular, Adam J. Hirsch, for the opportunity to present these ideas and to receive thoughtful suggestions and critique. I'd also like to thank Bonnie Marie Boryca and the editors at the Kansas Law Review for their deft and graceful editing.

1. John P. Dawson, Economic Duress-An Essay in Perspective, 45 Mich. L. REV. 253, 265 (1947).

2. For the argument that law courts lack the expertise to apply equity, see generally JUSTICE JoSEPH Story, COMMENTARIES ON EQUiTy JURISPRUDENCE §§ 59-64 (A.E. Randall ed., Sweet and Maxwell, Ltd., 3d ed. 1920); Sir Anthony Mason, The Impact of Equitable Doctrine on the Law of Contract, 27 ANGLO-AM. L. REV. 1 (1998).

3. See, e.g., Melson v. Melson, 711 A.2d 783, 789 (Del. 1998) (Berger, J., dissenting) (expressing the concern that "a will proponent saddled with the burden of proving the absence of undue influence will rarely be able to satisfy that burden").

4. See infra Part III.A.2.
} 
have effects that do violence to the goals for which the doctrine was supposedly developed. Rather than protecting testamentary freedom, it is a means to keep inheritance within families, or at least within relationships fitting preconceived social norms. ${ }^{5}$ Beyond its failures as a legal doctrine, undue influence also fails to achieve the policy goals often cited to justify its continued existence-most commonly, protecting the elderly from exploitation. ${ }^{6}$ Attempts to soften the effects of the doctrine, such as the Restatement's inclusion of bequests to unmarried partners and voluntary caregivers among those not presumed to be the result of undue influence, ${ }^{7}$ fail to redress the doctrine's harms.

The unsatisfactory doctrine of undue influence challenges us to decide what we, as a society, care about. If we care about protecting families, let legislatures institute forced heirship. If we value testamentary freedom over protecting families, let courts give it effect. If we care about the elderly, let us institute measures that will protect them more effectively than a doctrine that acts only after a testator's death. Whatever our social priorities, the conclusion is clear: the doctrine of undue influence must be abandoned.

Here is a seemingly egregious case of undue influence that also presents a typical scenario. In 1988, Roger Jacobs befriended the elderly Rose Lakatosh, who lived alone and estranged from her family "except for an occasional visit from her sister." 8 Over the following two years, Jacobs got into the habit of visiting Rose at least once, and often twice, a day. ${ }^{9}$ He also drove her to appointments and helped her with errands and

5. Almost every commentator who has criticized undue influence has made this point. See, e.g., Joseph W. deFuria, Testamentary Gifts Resulting from Meretricious Relationships: Undue Influence or Natural Beneficence?, 64 NOTRE DAME L. REV. 200, 200-02 (1989); Melanie B. Leslie, The Myth of Testamentary Freedom, 38 ARIZ. L. REV. 235, 236-37 (1996); Ray D. Madoff, Unmasking Undue Influence, 81 MiNN. L. REV. 571, 576-77 (1997); Jeffrey G. Sherman, Undue Influence and the Homosexual Testator, 42 U. PITT. L. REV. 225, 227 (1981); John H. Langbein, Will Contest, 103 YALE L.J. 2039, 2042 (1994) (reviewing DAVID MARGOLICK, UnDUE INFLUENCE: The EPIC BATTLE FOR THE Johnson \& Johnson ForTunE (1993)); Veena K. Murthy, Note, Undue Influence and Gender Stereotypes: Legal Doctrine or Indoctrination?, 4 CARDOZO WOMEN's L.J. 015, 106 (1997); Note, Will Contests on Trial, 6 STAN. L. REv.91, 95-96 (1953).

6. John F. Wasik, The Fleecing of America's Elderly, CONSUMERS DigeST, Mar./Apr. 2000, at 77, 77-78 (noting that the largest sector of elder abuse is financial). See also Cal. Law Revision Comm'n, Donative Transfer Restrictions, 38 CAL. L. REVISION COMM'N REP. 107, 113 (2008) (justifying the codification of undue influence doctrine because the elderly are especially susceptible to financial abuse); David Horton, The Uneasy Case for California's "Care Custodian" Statute, 12 CHAP. L. REV. 47, 53-55 (2008).

7. Restatement (Third) OF Prop.: Wills and Other Donative Transfers $\S 8.3 \mathrm{cmt} . \mathrm{f}$ (2003).

8. Estate of Lakatosh, 656 A.2d 1378, 1381 (Pa. Super. Ct. 1995).

9. Id. 
chores around the house. ${ }^{10}$ The court would later note that the "elderly woman came to depend on Roger as the only person with whom she really had substantial contact." A few months after they met, Jacobs suggested Lakatosh give him power of attorney "so that she would have someone to care for her should she need it," and she did so. ${ }^{12}$ She also drafted a new will, leaving all but $\$ 1000$ of her $\$ 268,000$ estate to Jacobs. ${ }^{13}$ The lawyer who drafted the will was Jacobs's second cousin. ${ }^{14}$ A tape recording of the will's execution would prove to the court that Rose had a "weakened intellect" and was easily distracted. ${ }^{15}$ She also seemed to suffer from delusions: she claimed her nephew was trying to kill her. ${ }^{16}$ Using the power of attorney, Jacobs transferred \$128,565.29 of Rose's money to himself and a girlfriend who was unknown to Lakatosh. ${ }^{17}$ By 1990, Lakatosh was living in "squalor and filth," neglecting to pay her sewer bills and taxes. ${ }^{18}$ She finally revoked the power of attorney on June 18, 1990. She died in November 1993, and the guardian of her estate contested the will. ${ }^{19}$ The court denied probate, finding the will was the product of undue influence. ${ }^{20}$

Having presented a case of undue influence in its most egregious form, how can I argue for the doctrine's abolition? My answer is fourfold. First, the doctrine did nothing to protect Rose Lakatosh while she was alive and being robbed of her means of support. Second, it is not clear how fair it is for the relatives who abandoned her to gain at the expense of someone who, at least for a time, gave her companionship and help in her daily life, and whom Rose described to the lawyer who drafted the will, as an "angel of mercy" who lifted her up when she had been "so low in hell." 21 Third, the Lakatosh will, like many others produced under similar circumstances, could have been invalidated on other grounds. Fourth, even if the elimination of undue influence made it impossible to invalidate the Lakatosh will, that result would be less unjust than the overall injustices resulting from leaving the doctrine in

\footnotetext{
10. Id.

11. Id.

12. Id. at $1381-82$

13. Id. at $1382-83$

14. Id. at $1381-82$

15. Id. at 1384 .

16. Id. at 1385 .

17. Id. at 1382 .

18. Id.

19. Id.

20. Id.

21. Id. at 1385 .
} 
place. In other words, Jacobs's benefiting from the will would be an acceptable price for the abolition of a doctrine that has been distorted beyond historical recognition, impairs testamentary freedom, fails to comport with psychological reality, forces courts to implement policies properly left to the legislative process, and fails to further the policies ostensibly undergirding it. Ultimately, however, I will also argue that leaving Rose Lakatosh's revised will in place would not have amounted to as severe an injustice as the above summary may make it appear. Indeed, I will show that often wills like the one in Lakatosh are less unfair than they first appear.

Many articles have criticized various aspects of the doctrine, ${ }^{22}$ most saliently, perhaps, two. First, in The Myth of Testamentary Freedom, Melanie Leslie argues that the doctrine, despite exalting testamentary freedom, in reality undermines it by protecting socially approved ways to dispose of property, and invalidating wills that fail to conform to social norms. ${ }^{23}$ Second, in Unmasking Undue Influence, Ray Madoff argues that the doctrine of undue influence itself has nothing to do with testamentary freedom, but rather exists to keep wealth in families. ${ }^{24}$ Madoff ultimately asks whether keeping wealth in families is desirable, and suggests that the future of undue influence doctrine depends on the answer. $^{25}$ I respond to Madoff's question by arguing that this is a legislative decision and challenging legislatures to make it.

Part II presents the history of the doctrine as it evolved from an overt tool to keep wealth within family and class lines to a legal one that purported to protect testamentary freedom. Part III summarizes the work of other scholars showing that the doctrine fails to achieve its purported goals of protecting testamentary intent, and, instead, often ignores such intent in the interest of maintaining social norms. Part III then addresses the two main reasons for the doctrine's failure. First, the notion of self underlying courts' decisions in undue influence cases fails to comport with the findings of contemporary psychology and, in fact, undermines the very testamentary autonomy the doctrine claims to protect. Exercising a misguided notion of individual autonomy, juries often fail to recognize valid interdependent relationships between testators and non-relatives because such relationships do not conform to jurors'

22. In addition to the articles by Leslie and Madoff, other articles criticizing the doctrine abound. See sources cited supra note 5 .

23. Leslie, supra note 5, at 236-37.

24. Madoff, supra note 5 , at 576.

25. Id. at 629 . 
personal experiences. ${ }^{26}$ When juries do recognize such relationships, they do so because the relationship in question reflects their own experiences of interdependence. ${ }^{27}$ This practice does little to advance testamentary freedom. The principle of testamentary freedom is not necessary to protect conventional bequests that conform to general experience; rather, it exists to carry out devises that fail to conform to social norms yet reflect the testator's will. Second, the doctrine has failed because it is so vague that it allows courts to reinforce these, and other, biases.

Part IV shows how the continued use of the doctrine generates serious costs, both in litigation and in threats of litigation. Part V isolates the policy concerns-protecting the elderly from coercion and overreaching, and protecting a testator from future mental decline- that underlie the doctrine and outlines other legal doctrines that better serve these policies. Part VI suggests more effective ways to protect elders without undermining testamentary freedom through crime solving and stricter will requirements. Finally, Part VII challenges us as a society to decide how much we care about keeping money in families, and if we do care, it challenges us to enact statutory schemes that protect family members.

\section{HISTORY}

The history of undue influence sheds light on the question of how and why the doctrine has become distorted. In England, the policy of contesting wills deemed to be the result of unfair or unconscionable dealing began as an equitable action available in the courts of Chancery, a twin to the idea of invalidating technically valid contracts deemed to be the result of overreaching. ${ }^{28}$ While ecclesiastical courts had jurisdiction over wills concerning personal property ${ }^{29}$ (until 1540 land could not be passed by will), there are no instances of will contests in ecclesiastical courts. Moreover, by the Reformation, Chancery and other equity courts

26. Melanie Leslie, Enforcing Family Promises: Reliance, Reciprocity and Relational Contract, 77 N.C. L. REV. 551, 571, 585 (1999) (noting that the "assumption that family members who have conformed with the reciprocity norm will inherit is so strong that it is akin to an implied promise" and that "[j]udges and juries have internalized societal norms concerning relationship formation and development").

27. Id.

28. See generally Michael M. Sheehan, The Will in Medieval England 165-76 (1963) (discussing the division of jurisdiction over will contests between civil and ecclesiastical courts); Dawson, supra note 1, at 262.

29. James Brundage, Medieval Canon Law 71-72 (David Bates ed., 1995); R. H. HelmholtZ, Roman CANON LAW In REFoRmation ENGLAND 1 (J. H. Baker ed., 1990). 
had jurisdiction over probate matters and offered ecclesiastical courts competition in this area. ${ }^{30}$ Over time, jurisdiction over these cases gradually shifted from Chancery to law courts for a number of reasons: competition for business led law courts to become more willing to hear equitable causes of action; ${ }^{31}$ litigants in cases involving real property often found their way into Chancery; and, law and equity were finally officially merged in the nineteenth century. ${ }^{32}$

This shift in jurisdiction played a significant role in turning the doctrine into the vague and destructive one it is today. The differences between equity and law made the transportation of an equitable doctrine into law highly problematic. The equitable doctrine that shaped undue influence developed from "radically different" premises than those which underlay the growth of common law. ${ }^{33}$ Courts of law employed different reasoning and logic than those of equity. ${ }^{34}$ An examination of the early cases and the trajectory of the doctrine supports this argument. ${ }^{35}$

30. BRUNDAGE, supra note 29, at 89; HELMHOLTZ, supra note 29, at 80.

31. J. H. BAKER, AN INTRODUCTION TO ENGLISH LEGAL HiSTORY 113-15 (4th ed. 2002).

32. Id. at $114-15$.

33. Dawson, supra note 1 , at 262.

34. BAKER, supra note 31 , at 114

35. Before the Chancery cases, the Institutes of Justinian may be a possible early source for undue influence: a scenario involving the so-called "unduteous will," in Latin, testamentum inofficiosum, in which a parent left his estate to someone other than his offspring. Disinherited children could bring an action based on the legal fiction that their parents were insane at the time they made the will. According to the Institutes,

Since parents often disinherit their children, or omit them in their testaments, without any cause, children who complain that they have been unjustly disinherited or omitted, have been permitted to bring the action de inofficioso testamento, on the supposition that their parents were not of sane mind when they made their testament. This does not mean that the testator was really insane, but that the testament, though regularly made, is inconsistent with the duty of affection the parent owes.

J. INST. D.v.2.2, 3.5 (Thomas Collett Sanders ed. \& trans., 4th ed., Longmans, Green, \& Co. 1869). Moreover, parents could also attack wills of their children as inofficiosi, and "brothers and sisters of a testator, also ... are preferred to infamous persons, if any such have been instituted heirs." Id. The Latin bears looking at in both cases because it bears the traces of an equitable, rather than a legal, formulation. The term inofficioso, used to describe a will that disinherited children, derived from the term officium pietatis, which referred to a person's duty to the gods or to those to whom one was related or bound by some other obligation. Wills that disinherited children failed in this duty to the testator's offspring and family, and were thus considered "at variance with the dictates of natural affection." Id., editorial note. The word "infamous" in the second quote translates the Latin turpis, an adjective whose root meaning is physically disgusting or morally disgraceful. Id. As the Latin makes clear, concern about enforcing social propriety against those seen as outsiders has long been a goal of the law of wills. Unduteous wills were so contrary to what was considered natural that the legal fiction of insanity seemed to be a perfectly appropriate remedy for them. Ties of consanguinity were at the heart of this provision: only children adopted by relatives could bring the action; those adopted by strangers had no access to it. Id. This law uses a legal fiction-a parent's insanity - to achieve the social goal seen most fair and conscionable, children's inheritance. Like doctrines in equity later, the Roman law explicitly aimed to fix an injustice the law would otherwise allow, and it unabashedly tells a lie to do so. 
Equity's mandate was different from that of the law courts: Chancery's function was to supplement the common law and to alleviate some of the harsher results which rigid application of common law rules could produce. ${ }^{36}$ Among other things, equity sought to protect those who, though they had technical legal capacity, had mental or physical impairments which left them vulnerable to exploitative, though valid, bargains. ${ }^{37}$ Equity thus enforced rules of conscience and contemporary ethics. $^{38}$ Equity, based in conscience, was embedded in religious teaching: indeed, most medieval chancellors were Bishops, trained in the Church. ${ }^{39}$ The Chancellor's role was to see that justice was done when the mechanical application of legal rules failed to achieve it. ${ }^{40}$ Part of this project involved preventing the "weak and foolish" from being taken advantage of by technically legal but unfair contracts. ${ }^{41}$ A crucial aspect of this process was that each decision was based narrowly on the facts of the particular case and had no effect on general rules of law; each decision was binding only on the parties, not on any future litigants in either court. ${ }^{42}$ Indeed, the judge in a Chancery case sat as both judge and jury, delving deeply into the facts of each case, declining to make a clear distinction between facts and law. ${ }^{43}$ As Lord Ellesmere put it in 1615,

men's actions are so diverse and infinite that it is impossible to make a general law which may aptly meet with every particular and not fail in some circumstances. The office of the chancellor is to correct men's consciences for frauds, breaches of trust, wrongs and oppressions of what nature soever they be, and to soften and mollify the extremity of the law. 44

Early English legal commentary and cases are devoid of the term "undue influence." A treatise by Henry Swinburne taught that a will "made by feare" was voidable, ${ }^{45}$ and that the "testament is to bee repelled which is made upon just feare," for such fear can make a man "sweare with his mouth, to performe that thing which he intendeth not in his

6. Mason, supra note 2, at 1 .

37. Dawson, supra note 1 , at 262.

38. Id.

39. BAKER, supra note 31 , at 99.

40. Id. at $102-03$.

41. Id. at 104

42. Id.

43. Id. at 106; see generally John H. Langbein, Fact Finding in the English Court of Chancery: A Rebuttal, 83 YALE L.J. 1620, 1629-30 (1974) (discussing the chancellor's role as fact finder).

44. BAKER, supra note 31, at 106 (quoting Earl of Oxford's Case (1615), 1 Rep. Ch. 1, 6).

45. Henry Swinburne, A Briefe TrEatise of Testaments AND LAST WiLles 241 (1611). 
heart." ${ }^{46}$ There are certain limitations to this rule, however: first, a will induced by fear is not void but voidable. ${ }^{47}$ Swinburne explains that such a will cannot automatically - ipso jure-be void by operation of law alone because "he that doth an act through feare, doth after a sort consent, that is to say, of two evils he chuseth the lesse, and is willing rather to make a testament, then to incurre the perill threatned." 48

This passage makes a profound point about free will, which became lost in the centuries following, but which Aristotle and Aquinas both understood. Aquinas disagreed with the proposition that an act taken out of fear is involuntary. ${ }^{49}$ Strictly speaking, he reasoned, such an act is voluntary because it is based on a choice. ${ }^{50}$ For example, if I give my watch to a mugger who is holding a gun to my head, the fact of the matter is that I am making a choice between loss of my watch and survival. ${ }^{51}$ This is not to say that relinquishing my watch is an act I would generally choose to perform; it is true that I am doing something I do not want to do, something that "goes against my grain." ${ }^{52}$ But in the concrete circumstances at issue, I do indeed want to do it because I want something else more - not to be killed. ${ }^{53}$ In some sense, then, the act of handing over my watch is involuntary, but to frame the decision in terms of free will is misleading. Aristotle, for his part, calls acts taken under duress, such as throwing one's goods overboard in a storm, "mixed, although they seem more like voluntary actions than involuntary ones; because at the time that they are performed they are matters of choice...." ${ }^{, 54}$ These examples do not underestimate the power of duress, but they do suggest the difficulty of an inquiry into whether an act was completely "free" and the product of one person's will rather than another's. One of the unfortunate aspects of the trajectory of the undue influence doctrine is that it led from equitable considerations based on the circumstances of the case to an abstract search for pure "free will," which, as this discussion indicates, is a futile one. More importantly, this trajectory illuminates a distinction between law and equity. While a law court would likely hold a contract—or a will—valid

\footnotetext{
46. Id. at $240-41$.

47. Id. at 241

48. Id.

49. Ralph McInerny, Ethica Thomistica: The Moral Philosophy of Thomas Aquinas 63-64 (1997)

50. Id. at 64

51. Id. at 63 .

52. Id.

53. Id.

54. ARistotle, Nicomachean EthiCs 50-51 (J.A.K. trans., Penguin Books 2004).
} 
because, as a technical matter, the contracting party or testator did "after a sort consent," equity could look at what he "intendeth in his heart." 55

Swinburne's treatise also defined impermissible pressure as "importunate," which the author explained as "gap[ing] and cry[ing] upon the Testator and not to be content with the first or second Denial." Again, this rule demands the kind of fact-intensive analysis for which equity courts were uniquely suited. Consistent with the slightly expansive meaning of "importunate," the early English cases express the broader equitable policy of invalidating wills or inter vivos conveyances that the court deemed to be the result of some kind of unconscionability less specific than fear. These cases reveal two notable features. One, as noted previously, the phrase "undue influence" did not appear. Rather, the courts used words like "practice," "fraud," "procurement," and "circumvention" to refer to illicit or unconscionable means of obtaining a will. The words "practice" and "circumvention" both referred to trickery, or, in other words, fraud and deception of some kind. "Practice" indicated something devious, a sleight of hand. The Oxford English Dictionary gives its meaning in the early 1600s as "scheming or planning... in an underhand way," including "[c]onspiracy" and "intrigue.", "Circumvention" goes back to the early sixteenth century, meaning "getting the better of any one by craft or artifice." 58

An English case from 1627, for example, invalidated a will because the court determined that the defendant beneficiary "procured" the testator who was old and "very weak" to make a new will through "Circumvention, Fraud and Practice." 59 The Chancery Court found that 'altho' the said Deeds and Will were not void in Law, as not being made by a Man of non sane Memory, yet so much thereof as was drawn from him by Practice and Circumvention ought to be made void in Equity." The court fails to mention any specific instances of fraud, stating merely that the decedent was "a very weak Man, and apt to be circumvented." Rather, it uses synonyms for fraud, and the word "fraud" itself, to signal something-perhaps literal fraud, perhaps something merely unconscionable - in the conveyance. ${ }^{62}$ Whereas a law court would have

55. SWINBURNE, supra note 45 , at 241.

56. Id. at 479 .

57. 12 THE OXFORD ENGLISH DiCTIONARY 271 (2d ed., 1989).

58. 3 THE OXFORD ENGLISH DICTIONARY 243 (2d ed., 1989).

59. Herbert v. Lowns, (1628) 21 Eng. Rep. 495, 496 (Ch.).

60. Id.

61. Id.

62. Id. Like the Institute's fiction of parental insanity, the fraud here may serve as a fiction allowing the court to reach its goal of voiding an unfair transaction without finding tangible evidence 
to find literal trickery to invalidate the contract, the equity court is free to use the words for trickery to undo an injustice, even if it did not uncover literal deceit.

The second notable feature of these decisions is that they clearly emanate from the perceived need to keep money in the family - and not just in the legal family. Their concern is the genetic family, referred to as the "Name and Blood" of the decedent. The essence of the injustice in these cases was a will that took the land away from the decedent's heirs "who of Right it doth belong to by Law." In Aynsworth v. Pollard, the decedent left the residue of his estate, after debts and legacies, to one Mary Pollard, "a lewd Woman [who] had abused" the decedent, but, strangely, given the court's interpretation, "whom he intended to marry." 64 The court "dislik[ed] that the Estate of the [decedent] should be given away from his own Child to the said Mary Pollard, who hath and had an Husband living at the Time of the said Will," and directed the residue of the estate go to the testator's daughter. ${ }^{65}$ In 1638, the Court of Chancery implicitly agreed that a will which settled the decedent's lands on his wife and her issue "out of the [husband's] Name and Blood" was "contrived by the Defendant [wife]" and was an "inofficious Will seeking to prefer Strangers before Name and Blood." 66 Here, again, it seems likely that the word "contrived" functioned as a fiction to help the court reach its goal: it adduces no evidence of actual deceit, as the word implies, but uses the concept as an excuse to invalidate the will.

Again, in 1663, the Court of Chancery found that a defendant in a will contest "by Practice got [the decedent] to make another Will" which unjustly "disinherit[ed] an Heir and only Child, being innocent and inoffensive, and to introduce Strangers without any Reason of Affinity or Merit." ${ }^{67}$ The court's concern here was to invalidate a will it deemed to work an injustice and to enforce social policy; it spent little time seeking facts to prove literal deceit.

The social agenda that the Chancery courts sought to carry out with respect to wills emerged most clearly in the eighteenth century when the court started using its discretion to keep the estates of aristocratic families out of the hands of lower-class creditors. This policy received

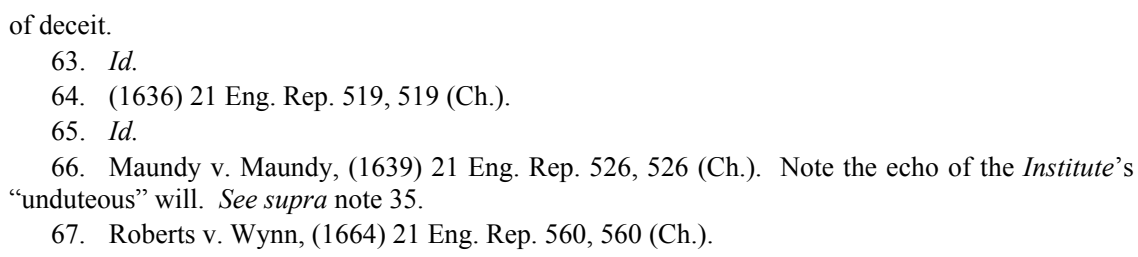


its fullest exposition in Earl of Chesterfield v. Sir Abraham Janssen, ${ }^{68}$ although this particular ruling did not give the heir all the relief he had requested. ${ }^{69}$ An expectant heir-to the Duchess of Marlborough, no less-borrowed five thousand pounds on bond to pay ten thousand on the death of the Duchess, upon which he reaffirmed the deal with a new bond and paid part of it. ${ }^{70}$ The heir survived the Duchess by one year and eight months, and at his death the parties petitioned for payment and relief, respectively. ${ }^{71}$ The estate's lawyers asserted that the case was of great importance not only to the estate but "of greater to the public" because of the growing evil of "unreasonable bargains in case[s] of young heirs." 72 The Lord Chancellor agreed in principle, referring to the policy concerns of "preventing the ruin of families," and explained that a contract to borrow on expectation was a species of fraud against which the equity courts were particularly suited to grant relief. ${ }^{73}$ Such bargains with heirs constituted fraud because they perpetrated a fraud on persons not privy to the agreement, namely, "the father, ancestor, or relation ... who has been seduced to leave his estate not to his heir or family, but to a set of artful persons, who have divided the spoil beforehand." ${ }^{74}$ The Chancellor took care to observe that there was no "actual fraud" here, but there was "deceit upon her [the Duchess] who was in loco parentis, from whom were his great expectations," meaning that she had, in effect, left her estate to creditors, which had not been her intention. ${ }^{75}$ Consistent with the equity decisions already discussed, this court sought to alleviate a social harm even though it failed to find actual fraud or illegality of any kind. ${ }^{76}$ This undertaking is typical of equity courts, and it makes explicit what is actually going on in these cases.

Similarly, in 1684, the Earl of Arglasse asked the Court to relieve him of a grant of rent out of his lands made to the defendant by his nephew, the now deceased Earl, claiming that the grant was an "unconscionable bargain... obtained by fraud and practice, by debauching Earl Thomas with drink and women."77 The initial

68. (1751) 28 Eng. Rep. 82 (Ch.). Although a "Sir," the proponent in this case was clearly of a lower class than the Earl, and may have purchased his title.

69. Id. at 85 .

70. Id. at 82

71. Id. The court explained that "it did not clearly appear" which party made the first petition. Id.

72. Id. at 83,84 .

73. Id. at 101 (concurring opinion).

74. Id.

75. Id.

76. Id. at 102 .

77. Earl of Arglasse v. Muschamp, (1684) 23 Eng. Rep. 438, 438 (Ch.). 
complaint simply alleged fraud, whereupon the Lord Keeper declared that setting aside the grant would be too great "a violation upon contracts," and advised the plaintiff to amend. ${ }^{78}$

At his rehearing, the plaintiff cannily introduced the theme of the expectant heir, noting that ample precedent existed to set aside "unconscionable bargains, which had been made with young heirs," and that at the time of the grant, the "earl was very young, and had forsaken his wife and her friends in Ireland, and lived here in London in riot and debauchery, and for supply of his expences had made this bargain, without the advice of any friends or counsel of his own." 79 He also observed that the grant was conditioned on the Earl dying without male heirs, a possibility, he claimed, the Earl's surgeon had told the defendant to be medically likely, ${ }^{80}$ and that the defendant, having been tipped off by the surgeon, had received "an unreasonable advantage." 81 At this point, the court agreed that the grant should be released. ${ }^{82}$ Notably, the court was moved to take the fraud claim seriously only when it was coupled with the policy consideration of protecting the expectant heir. Because there seems to have been no actual fraud, the court creates a fiction to replace it. Indeed, it is just as easy to read the defendant's gamble as just that - sound commercial practice, a good bet, based on information equally available to the Earl as to him. Moreover, an alternate reading of the case might see the Earl as using his inability to produce heirs as a lucky break, allowing him to borrow money he needed at the time, perhaps knowing he could dispose of the contract later.

In Berney v. Pitt, in 1686, the Chancery revoked a bargain by which a young heir to a "great estate" borrowed two thousand pounds to pay off his debts in return for a promise to pay between five thousand and ten thousand upon his inheritance. ${ }^{83}$ When his father died, the plaintiff brought suit alleging fraud and "working upon the plaintiff's necessity when in streights." 84 The first hearing went against him: the court found that because the defendant stood to lose everything if the heir died before the father, no basis existed to vacate the bargain. ${ }^{85}$ Upon rehearing, however, the plaintiff, like the plaintiff in Arglasse, reminded the court that this was an expectant heir case, arguing that the defeasance "did not

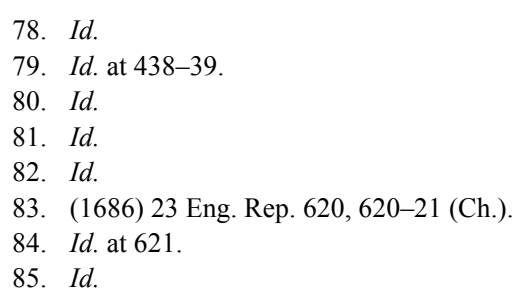


differ the case in reason at all from any other bargain made by [a] plaintiff ... to be paid at their father's death" - in fact, he asserted, the defeasance was only there to appear to assuage what even the defendant recognized as an unconscionable bargain. ${ }^{86}$ The Lord Chancellor agreed, and "thought there was not in this case any proof of any practice used by the defendant... to draw the plaintiff into this security, yet in respect merely to the unconscionableness of the bargain" he discharged the voided agreement, ordering the defendant to refund all the money less the original loan with statutory interest. ${ }^{87}$

The court made no secret of what it was doing. In Berney, the court said "these Bargains ... tended to the Destruction of Heirs ... and to the utter Ruin of Families," ${ }^{, 8}$ and a judge in Earl of Portmore v. Taylor added:

The mere fact that Lord Portmore was not only an Heir Apparent to his Father, but also the expectant heir to a Peerage also brings the Case distinctly within the Rule laid down by this Court ... [not to] allow an Heir of a Family of Rank to be reduced to poverty and distress by dealing with his expectances. ${ }^{89}$

These cases display the virtue of honesty: they openly declare their desire to maintain wealth within family lines. This is the kind of extralegal consideration that Chancery judges were supposed to employ in their decisions, but, as will become clear, it is one ill-suited to law courts. One law judge remarked sarcastically that to expectant heirs, the Court of Chancery "seems to have extended a degree of protection, approaching nearly to incapacitate them from binding themselves by any contract." 90

To understand the policy courts were implementing, and how deeply embedded it was in the socio-economic anxieties of the time, I turn to a non-legal text that reflects the same concerns. Such an examination hints at how much was at stake in these decisions and foreshadows the danger of their removal to courts of law. Who, then, are these "artful persons" who have "divided the spoil beforehand?" The Oxford English Dictionary confirms that the word "artful" had negative connotations in the eighteenth and nineteenth centuries, and referred to deceitful and

86. Id.

87. Id.

88. (1686) 21 Eng. Rep. 697, 698 (Ch.).

89. Dawson, supra note 1, at 268, n.37 (quoting Earl of Portmore v. Taylor, (1831) 4 Sim. 182, 213 (Ch.)).

90. Peacock v. Evans, (1809) 33 Eng. Rep. 1079, 1079 (Ch.). 
underhanded practices. ${ }^{91}$ Charles Dickens, however, may also come to mind. Here is the Artful Dodger making his first appearance in Oliver Twist:

He was a snub-nosed, flat-browed, common-faced boy enough; and as dirty a juvenile as one could wish to see; but he had about him all the airs and manners of a man. He was short of his age: with rather bowlegs, and little sharp, ugly eyes. ... He wore a man's coat, which reached nearly to his heels. He had turned the cuffs back, half-way up his arm, to get his hands out of the sleeves: apparently with ultimate view of thrusting them into the pockets of his corduroy trousers; for there he kept them. He was, altogether, as roystering and swaggering a young gentle-man as ever stood four feet six, or something less, in his bluchers [i.e., boots].

I introduce this passage to make a point about equity and the way it supplements the law by enforcing social norms in a way that law cannot. Dickens's description here sheds light on the early Victorian meaning of the word "artful" and on the norm construction both texts - the legal and the literary-engage in. As I have suggested, the courts were concerned with keeping money in aristocratic families, and out of the hands of lower class creditors. To Dickens the "artful" was not only indicative of the clearly marked lower class but an atavistic description as well: he is "flat-browed and common-faced," of intellect and his lack of any worthwhile "Name and Blood." Indeed, the whole novel Oliver Twist is deeply concerned with keeping money within family and class lines. The plot follows Oliver from his childhood in an orphanage to his eventual discovery of his aristocratic heritage, ultimately saving his inheritance from the lower class scoundrels and Fagin the Jew who sought to hide it from him.

This passage, read alongside the cases above, reveals an important aspect of the role of equity distinct from that of law. Equity courts enforce social norms of the time, which later ages may find anachronistic or disagreeable. Dickens's Artful Dodger embodies the shadow side of the impulse to keep wealth in families described above, a shadow whose distastefulness may appear more clearly to modern eyes than to Victorian ones. Equity is better positioned to perform this role for two reasons. Its decisions make explicit the social norms they are enforcing, and it, therefore, does not calcify these norms into mechanically applicable legal

\footnotetext{
91. 1 The OXFORD ENGLiSh DiCTIONARY 661 (2d ed., 1989).

92. Charles Dickens, Oliver Twist 43-44 (Airmont Publishing Co., 1963) (1838).

93. Id.
} 
rules which then, abstracted from their context, carry them into future ages when the underlying biases no longer reflect social consensus.

In 1728, a law court reversed a decree of the Court of Chancery regarding the validity of a will on the grounds that Chancery had no jurisdiction over will contests. This was also the first case which used the phrase "undue influence." 94 While courts of equity used such terms as "fraud" and "practice" as fictions to allow them to reach desired results under the circumstances of each case, law courts like this one were looking for actual truth and hard and fast rules, which could bind not just the parties of the moment, but parties in future cases. For example, an 1838 appeal from the Prerogative Court ${ }^{95}$ tried to define "undue influence and importunity" sufficient to defeat a will: it is "fraud or duress, exercised on a mind in a state of debility." 96 This early example already betrays signs of vagueness and confusion. Would not "fraud or duress" exercised upon a strong mind also suffice to defeat a will? The modification "on a mind in a state of debility" seems to leave open the possibility that something less than actual "fraud and duress" might constitute undue influence when exercised on a mind in such a state. An 1848 case, another appeal from the Prerogative Court of Canterbury (which had jurisdiction over wills and intestates' estates for those who left personal property of more than five pounds worth within the province of Canterbury ${ }^{97}$ ) refers to undue influence as a "species of duress." 98 This is precisely not the point: its origins make clear that is a species of unconscionability. This confusion persists today: some casebooks try to claim that coercion is an element of undue influence, but it is clear from the cases that it is not.

By 1868 , the doctrine had shifted to a new and unfortunate track. The Court of Probate and Divorce, a law court, now described undue influence as "pressure ... so exerted as to overpower the volition without convincing the judgment... though no force is either used or threatened." 99 Thus, the determination was no longer whether a person's will had been constrained more than a court's conscience considered

94. Kerrich v. Bransby, (1727) 3 Eng. Rep. 284, 284 (H.L.).

95. The Prerogative Court was a probate court under the Archbishop of York or the Archbishop of Canterbury, which had jurisdiction when a testator left goods of a certain value in a diocese other than that in which he died. Peter D. Jason, The Courts Christian in Medieval England, 37 CATH. LAW. 339, 350-51 (1997).

96. Barry v. Butlin, (1838) 12 Eng. Rep. 1089, 1093 (P.C.).

97. Lloyd Bonfield, Reforming the Requirements for Due Execution of Wills: Some Guidance From the Past, 70 TUL. L. REV. 1893, 1910 (1996).

98. Browning v. Budd, (1848) 13 Eng. Rep. 749, 751 (P.C.).

99. Hall v. Hall, (1868) 1 L.R.P. \& D. 481, 481 (P. \& D.). 
fair. ${ }^{100}$ Now, the Court tries to answer the unanswerable question of whether the influenced person had exercised free will. ${ }^{101}$ This is a completely different inquiry and, as I will show, one impossible to conclude. $^{102}$

In 1885, Lord Hannen summarized the new common law of undue influence as follows:

We are all familiar with the use of the word "influence"; we say that one person has unbounded influence over another, and we speak of evil influences and good influences, but it is not because one person has unbounded influence over another that therefore when exercised, even though it may be very bad indeed, it is undue influence in the legal sense of the word. To give you some illustration of what I mean, a young man may be caught in the toils of a harlot, who makes use of her influence to induce him to make a will in her favour, to the exclusion of his relatives. It is unfortunately quite natural that a man so entangled should yield to that influence and confer large bounties on the person with whom he has been brought into such a relation; yet the law does not attempt to guard against those contingencies. A man may be the companion of another, and may encourage him in evil courses, and so obtain what is called an undue influence over him, and the consequence may be a will made in his favour. But that again, shocking as it is, perhaps even worse than the other, will not amount to undue influence.

To be undue influence in the eye of the law there must be - to sum it up in a word-coercion.... It is only when the will of the person who becomes a testator is coerced into doing that which he or she does not desire to do, that it is undue influence.

The coercion may of course be of different kinds, it may be in the grossest form, such as actual confinement or violence, or a person in the last days or hours of life may have become so weak and feeble, that a very little pressure will be sufficient to bring about the desired result, and it may even be, that the mere talking to him at that stage of illness and pressing something upon him may so fatigue the brain, that the sick person may be induced, for quietness' sake, to do anything. This would equally be coercion, though not actual violence. ${ }^{103}$

This attempt at a definition clearly moved the inquiry from one about conscionability to one about the line between free and suppressed will.

100. See Dawson, supra note 1, at 263-65 (describing the change in the late nineteenth century where courts broadened undue influence so that it covered more than just cases "of mental and physical weakness").

101. Id. at 266 .

102. See id. at 262-66 (describing the change in the definition of undue influence during the end of the nineteenth century).

103. Wingrove v. Wingrove, (1885) 11 P.D. 81,88 (P. \& D.). 
The question was no longer whether there was a degree of unfairness in the transaction sufficient to nullify it. Now the question was whether the "will" of the testator was his own or someone else's. This definition draws a bright line in the common law of wills, rather than examining degrees of unfairness in the light of surrounding circumstances as equity courts had been doing.

The English history of this doctrine, then, involved a gradual and unfortunate change in its meaning as a result of this equitable doctrine's integration into law courts, whose approach was quite different than that of equity courts. The approaches of law and equity are fundamentally different, and they express different value systems. ${ }^{104}$ Equity's approach was to examine the specific factors of a case in order to serve the cause of fairness, or whatever the stated social goals of the moment were. Undue influence thus began as a way of enforcing the social goal of keeping wealth in families. When law courts began applying the doctrine, however, their approach was based in law rather than equity: they sought predictability and formulated fixed, abstract legal rules that could be generalized from the facts of a given situation, rather than applying notions of conscience to particular circumstances. Thus law courts transformed the doctrine into one which purported to protect testamentary freedom as a legal imperative, but which, in fact, retained its role, now obscured, of enforcing social norms. Unfortunately, this role became hidden under the notion of the testator's true "intent." This produced unfortunate results, as has been amply documented.

Even as applied in American law courts, undue influence has been subject to expansion over the past few decades. Early twentieth century casebooks still listed coercion or fraud as elements of the doctrine, ${ }^{105}$ and treatises defined coercion as "actual violence, of threats expressed or implied, or of harassing importunity." ${ }^{106}$ An early textbook itemized the kinds of influence that fail to qualify as undue:

considerations addressed to a testator's good feelings, simply influencing his better judgment; the earnest solicitations of a wife, or the exercise of influence springing from family relations, or from motives of duty, affection, or gratitude; persuasion, argument, or

104. Mason, supra note 2, at 3 .

105. The LaW of Decedents' Estates Including Wills $\S 22$ (WM. F. Woerner and F. A.Wislizenus eds., 1913).

106. JOHN R. RoOD, A TREATISE ON THE LAW OF WiLls § 175 (1904). 
flattery; kindness and attentions to the testator; and influence worthily exerted for the benefit of others .... ${ }^{10}$

The doctrine's liberalization began shortly thereafter. Over the course of the early twentieth century, the English rule that undue influence was never presumed gave way to the presumption of undue influence in cases of wills benefitting a fiduciary of the testator. ${ }^{108}$ By the 1940s, when Atkinson published his treatise on the law of wills, force and even the broader coercion had receded in importance in favor of the notion that a will failed to express the testator's "true wish or desire."109

\section{THE DOCTRINE TODAY AND WHY IT Is NOT WORKING}

The elements of undue influence in American courts today are as follows: (1) the influencer had disposition or motive to exercise it, (2) the influencer had opportunity to exercise the influence, (3) the influencer did in fact exercise the influence, and (4) the testamentary disposition at issue was a result of the undue influence. ${ }^{110}$ Influence that rises to the level of "undue influence" sufficient to invalidate a will must be such as to "control the mental operations of the testator, overcome his power to resist and oblige him to adopt the will of another, thus inducing a testamentary disposition ... which the testator would not have made if left free to act according to his own wishes and pleasure."111 Such influence "must amount to over-persuasion, force or coercion, violence or threatened violence, [or] moral coercion...."112 To distinguish between lawful and unlawful influence, one case notes that "[p]ersuasion, appeals to the affection or ties of kindred, to sentiment of gratitude for past services, or pity for future destitution, or the likethese are legitimate, and may be fairly pressed on a testator." According to the Third Restatement of Property, undue influence occurs if a "wrongdoer exerted such influence over the donor that it overcame the donor's free will and caused the donor to make a donative transfer

107. THE LAW OF DECEDENTS' ESTATES, supra note 105, $§ 22$.

108. See generally Ronald J. Scalise Jr., Undue Influence and the Law of Wills: A Comparative Analysis, 19 DUKE J. COMP. \& INT'L L. 41, 48-53 (2008).

109. Thomas E. AtKInSON, HANDBOOK OF THE LAW OF Wills $\S 55$ (2d ed. 1953).

110. Restatement (Third) OF Prop.: Wills \& Other DONATIVE Transfers $\S 8.3 \mathrm{cmt}$. e (2003); Scalise, supra note 108, at 55.

111. R.L. ANAND, LAW OF UNDUE INFLUENCE, FRAUD AND DURESS 341 (1957).

112. Id.

113. Hall v. Hall, (1868) 1 L. R. P. \& D. 481, 482 (P. \& D.). 
the donor would not otherwise have made."114 The essence of the doctrine is that there exists a line beyond which a testator's bequests no longer reflect his own desires and inclinations, but rather reflect the desires and inclinations of another. The doctrine assumes that the influencer can achieve control of the testator's will through means other than force; a will that was the product of physical duress or coercion would be easy to invalidate on those grounds. Rather, the influencer uses means that fall short of actual physical coercion but which rise above mere affection, entreaty, or even repeated requests.

The procedural aspects of the doctrine allow for burden shifting. The burden of proof starts out on the person claiming the undue influence, the contestant. If the contestant can raise a rebuttable presumption of undue influence, the burden shifts to the party seeking to have the will admitted to probate, the proponent. ${ }^{115}$ Different jurisdictions allow the presumption to arise in different ways. In some, for example, the existence of a confidential relationship between the testator and the proponent is by itself enough to raise the presumption; ${ }^{116}$ in others, the confidential relationship must be accompanied by other suspicious circumstances, such as those listed in the Restatement:

(1) the extent to which the donor was in a weakened condition, physically, mentally, or both, and therefore susceptible to undue influence; (2) the extent to which the alleged wrongdoer participated in the preparation or procurement of the will or will substitute; (3) whether the donor received independent advice from ... disinterested advisors in preparing the will or will substitute; (4) whether the will ... was prepared in secrecy or in haste; (5) whether the donor's attitude toward others had changed by reason of his or her relationship with the alleged wrongdoer; (6) whether there is a decided discrepancy between a new and previous wills ...; (7) whether there was a continuity of purpose indicating a settled intent in the disposition of his or her property; and (8) whether the disposition of the property is such that a reasonable person would regard it as unnatural, unjust, or unfair, for example, whether the disposition abruptly and without apparent reason disinherited a faithful and deserving family member. ${ }^{117}$

Once the burden of proof has shifted, the will's proponent must disprove the existence of undue influence. In 1998, the Iowa Supreme Court said, in order to do this, the proponent had to disprove the basic

114. Restatement (Third) OF Prop.: Wills \& Other Donative Transfers $\S 8.3$ (2003).

115. Id. $\S 8.3 \mathrm{cmt} . \mathrm{f}$.

116. Id.

117. Id. $\S 8.3 \mathrm{cmt} . \mathrm{h}$. 
elements of undue influence, i.e., the "grantors lack of susceptibility," the alleged wrongdoer's "lack of opportunity to exercise undue influence," the "lack of disposition to influence unduly;" and a testamentary "result clearly unaffected by undue influence." 118 This is difficult to do-how does one prove the negative of "a disposition to influence unduly"- and the court does not explain why it would be necessary to disprove all the elements.

Judicial decisions admit that the doctrine resists precise definition. ${ }^{119}$ Indeed, some judges have regarded its very vagueness as a necessary element of the concept because "[a] precise definition would be hazardous, since the very definition itself would "furnish a fingerboard pointing out the very path by which it may be evaded." 120 The notion that courts should resist precise legal definitions to avoid putting wouldbe wrongdoers on notice of how to formulate their schemes does not comport with common law standards of notice, nor is it a sign of a resilient doctrine. Should a court avoid defining false imprisonment to avoid showing would-be offenders how to get away with it?

Casebooks seem uncomfortable with the doctrine. Most admit that the listed elements are not terribly helpful in spotting actual cases of undue influence since they beg the underlying question: what influence is undue influence? As one casebook puts it:

[G]iven the subtle and secret ways in which influence can be exercised, it is often difficult to establish by direct evidence precisely what was said or done to procure a particular testamentary disposition. Moreover ... the words and actions of the testator and other persons may be subject to radically different characterizations . . . .

Indeed, I will discuss in detail instances of just this kind of confusing and inconclusive evidence about words and relationships later in this Article. Another casebook even uses quotation marks to express skepticism about the very notion of undue influence, explaining that will contestants often "argue that the written will does not reflect the testator's 'true' intent." 122 It is also noteworthy that many casebooks offer negative examples: cases in which courts seem to have found undue influence based on sheer narrow-mindedness, rigid notions of social propriety, and outright

\footnotetext{
118. In re Estate of Todd, 585 N.W.2d 273, 277 n.5 (Iowa 1998).

119. Joseph TRAub ARENSON, The Doctrine of Undue INFLUENCE IN ANGLO AMERICAN LAW 3 (1953).

120. Id. (quoting Shipman v. Furniss, 69 Ala. 555, 565 (Ala. 1881)).

121. Elias Clark et al., Gratuitous Transfers 220 (5th ed. 2007).

122. Joel C. Dobris et Al., Estates AND TRUSTS 403 (2d ed. 2003).
} 
bigotry, such as In re Will of Kaufmann. ${ }^{123}$ As Professor Clark's casebook sums up: "the open-ended nature of the applicable legal standard leaves considerable leeway for a court or jury to bring its own views of morality and propriety to bear in determining whether a will was procured through undue influence." 124 Casebooks go on, however, to offer the "good" cases, those presented to show that the doctrine is necessary, when properly applied, to protect people-usually the elderly-from overreaching. ${ }^{125}$ Lakatosh, discussed in the introduction, is one such example.

In re Estate of Reid is another. ${ }^{126}$ A seventy-eight-year-old woman devised her estate to an unrelated twenty-four-year-old law student, whom she had also adopted. ${ }^{127}$ A casebook recounts the facts with a running undercurrent of sarcasm, noting that the proponent "made the most of his legal education," met the decedent by "expressing an educational interest in her historical antebellum home," "put his legal knowledge to work," and underwent the adoption "in a dramatic application of the 'belts and suspenders' approach to lawyering." 128 However, the documents introduced in the case, as discussed below, contain a significant amount of evidence of the decedent's clearly stated wish to adopt the young man and leave him her property to the detriment of relatives with whom she had little contact. ${ }^{129}$ Another casebook puts the Reid case in a note about wills which "exclude[] the testator's blood relatives in favor of a lover," 130 despite the fact that the court papers contain evidence that the physical affection between the decedent and the young man consisted of hugs, and that the testator regarded him as her son. ${ }^{131}$ My point here is not to contest the court's decision in Reid-I do that shortly - but rather to show that despite highlighting the biases of courts in earlier undue influence cases, many casebooks, and, perhaps, law school pedagogy itself do the same ideological work in a different context. Gone are prejudices against same sex partners; now the socially

123. 247 N.Y.S.2d 664 (N.Y. App. Div. 1964), reprinted in ESTATES AND TRUSTS, supra note 122 , at 445 .

124. CLARK ET AL., supra note 121, at 231.

125. See, e.g., DukEMiniER ET AL., Wills, TRUSTS AND Estates 191 (7th ed. 2005). Although the Dukeminier casebook seems skeptical about the doctrine, it also seems to offer the "bad, old" cases like Kaufmann, followed by the "good, new" cases like Lakatosh, a narrative sequence that implicitly justifies the continued existence of the doctrine. Id.

126. 825 So. $2 \mathrm{~d} 1$ (Miss. 2002) (en banc).

127. Id. at 4 .

128. DOBRIS ET AL., supra note 122, at 426-27.

129. Reid, 825 So. $2 \mathrm{~d}$ at 3-5. See also discussion infra Part III.B.2.

130. CLARK ET AL., supra note 121, at 229.

131. Reid, 825 So. $2 \mathrm{~d}$ at $3-5$. 
unacceptable is an older woman befriending and leaving a bequest to a younger man.

Further, when courts try to define undue influence, they usually confuse the doctrine more. For example, one court noted that " $[\mathrm{t}] \mathrm{he}$ word 'undue'... means a wrongful influence, but influence acquired through affection is not wrongful." 132 Does this mean that once there is an emotional bond between the parties - "affection"- that any kind of influence is acceptable? Surely most undue influence cases arise from some form of affection between a needy person and someone who supplies those needs, whether emotional or physical. Again, as an English Probate Court explained in 1868:

[A]ll influences are not unlawful. Persuasion, appeals to the affections or ties of kindred, to a sentiment of gratitude for past services, or pity for future destitution, or the like - these are all legitimate, and may be fairly pressed on a testator. On the other hand, pressure of whatever character, whether acting on the fears or the hopes, if so exerted as to overpower the volition without convincing the judgment [is unlawful]. ${ }^{133}$

A close reading of this definition increases confusion: what is the line between "persuasion," "appeals to affections" and "pressure?" Surely the emotion of guilt, so easily inspired by relatives, bridges the gulf between "affections" and "pressure"-indeed, it might be that the text itself subliminally undermines its own distinctions by using forms of the word "pressure" in both clauses on the opposite sides of the divide.

Another court twisted itself into knots over a similar stretch toward clarity, explaining that "advice, arguments, persuasions, solicitations, suggestions, or entreaties" are lawful, unless they are so "importunate, persistent, or coercive" so as to "subdue and subordinate the will of the testator ...."134 Are entreaties not by definition importunate? And if not, how does one tell when they become so? Does the word "argument" not imply a certain amount of "persistence" if not outright "coercion?" Another case falls even wider of the mark, asserting that "[r]ather than approach the problem from the standpoint of the testator's freedom of will, it would be more profitable to focus... on the nature of the influencer's conduct" and the "unfairness of the advantage which is

132. In re Estate of Webb, 863 P.2d 1116, 1121 (Okla. 1993) (quoting Canfield v. Canfield, 31 P.2d 152, 153 (Okla. 1934)).

133. Hall v. Hall, (1868) 1 L. R. P. \& D. 481 (P. \& D.).

134. In re Estate of Riley, 479 P.2d 1, 24 (Wash. 1970) (en banc) (citations omitted). 
reaped as the result of wrongful conduct."135 The doctrine, however, is meant to protect precisely that, a testator's free will; consciously putting that question aside and examining only the "naturalness" or fairness of the bequest seems anathema to the doctrine's ostensible goals. The Reddaway court's statement tautologically assumes the wrongful conduct. Once the focus shifts from the testator's intent to an outsider's judgment of the bequest, this assumption seems inevitable. This Mobiuslike logic is typical of the reasoning in undue influence cases, and compelling evidence that the doctrine does not comport with notions of legal fairness or notice. It is surprising, given all this, that no one has yet called for abolition of the doctrine.

The two most significant critiques of undue influence have come from Melanie Leslie and Ray Madoff. In The Myth of Testamentary Freedom, Leslie shows that juries "often evaluate potential beneficiaries from their own perspective, as opposed that of the testator, thus appearing less concerned with effectuating testamentary intent than in forcing the testator to distribute her or his estate in accordance with prevailing notions of morality." hypothesizes that courts and judges make these decisions based on notions of "relational contracts" in families, that is, the idea that over time a relationship of trust develops between family members who care for one another and trust that they will be provided for in testamentary bequests, and that juries are willing to enforce these "relational contracts." courts enforcing prevailing social norms, ${ }^{138}$ but if such relational contracts are the social norm, legislatures should pass laws to enforce them rather than leaving it to courts to do so underhandedly, while professing to apply a doctrine that was meant to achieve something else.

Madoff's article uncovers the work undue influence does in keeping wealth in families and calls for an evaluation of whether this is a legitimate or desirable social goal. ${ }^{139}$ Only if it is, she argues, is the doctrine legitimate. ${ }^{140}$ Both these scholars, as well as others, argue that the doctrine is failing to achieve its purported goal of protecting testamentary freedom; rather, they conclude, behind its "mask" of realizing a testator's true intent, it is doing something else entirely.

135. In re Estate of Reddaway, 329 P.2d 886, 890 (Okla. 1958) (en banc).

136. Leslie, supra note 5, at 246.

137. Leslie, supra note 26, at 571.

138. Id. at 585 .

139. Madoff, supra note 5 , at 576-77.

140. Id. at 619,629 . 
There are both psychological and doctrinal reasons that explain the "mask" and reveal what is going on behind it.

\section{A. Psychology}

The past hundred years of psychology, as well as recent clinical studies, indicate that the understanding of the "self" that courts use in deciding undue influence cases is deeply misguided. First, courts are illsuited to analyze, and even understand, the shifting operations of power in intimate relationships. As most psychologists agree, and clinical studies show, power in relationships is nuanced, complex, and nearly impossible to understand from the outside. The insights of psychology, with its emphasis on ambiguity and ambivalence, are an ill fit in the law's evidentiary paradigms. Second, courts assume that there is such a thing as a "fully autonomous self," and that the line between that self and the influence of others can be clearly demarcated. In cases when courts (and juries) do recognize that the self exists in relation to others, and is a product of those relationships, they acknowledge this fact only with respect to family members, and are thus deeply suspicious of interdependent relationships among unrelated adults. ${ }^{14}$

This lack of psychological sophistication has allowed the undue influence doctrine to work against its stated goals of preserving testamentary freedom, and continues to do so. This is because fact finders bring their own paradigms to the cases, and only recognize the relational nature of the self in the context of the family. This is unfortunate for two related reasons: psychology shows that the relational self is not limited to family connections, and, as alternative living arrangements and "families by choice" play a larger and larger role in our society, more and more people will wish to leave bequests to nonrelatives.

\section{Power in Relationships}

William Reik's analysis of masochism illuminates the problem with attempts to understand power in a relationship from the outside or without psychological training. A relationship can look from the outside as if one person has power over another and forces the other to do his will-in undue influence terms, "substitut[ing] his will for that of the

141. I thank Melanie Leslie for this formulation. 
other person" $" 142$ - but Reik points out that this appearance reflects a complicated reality and can be misleading. The hidden part of the dynamic is that the seemingly powerless partner actually uses his power to "force [the] other person to force him," that is, he induces the seemingly dominant partner to "create for him that discomfort which he needs for attaining his pleasure."143 Reik goes on to explain that the boundaries between the masochistic and the sadistic partner disappear, or even appear reversed for periods of time, thus destabilizing the notion of a consistent power dynamic whereby one person is controlled by the other. ${ }^{144}$ "The pain addict," Reik summarizes, "becomes a tormentor."

Recent clinical psychology has also challenged simplistic notions of power in relationships, particularly within marriage. For example, psychologists observed that power within conjugal relationships often varies from one domain to the next, and that each spouse's "role definition" determined where he or she had power. ${ }^{146}$ A wife might have more power when the issue was inviting friends over to the home, while the husband might have more power with respect to financial decisions. ${ }^{147}$

Indeed, even without recent studies in power relations between couples, it soon becomes clear that legal terms are a blunt instrument with which to parse psychological nuance in relationships. As Madoff puts it, the model of independent decision making "relies on the notions that (1) a person's natural state is one of independence from others ... and (2) for people who are dependent on other people, it is possible to determine what their intentions would be if they were not dependent."148 This is an overly simplistic scheme of human nature and human relationships. The famous Johnson \& Johnson case provides a good example. ${ }^{149}$

142. Phillips v. Chase, 89 N.E. 1049, 1050 (Mass. 1909).

143. THeOdOR ReIK, MASOCHISM IN MODERN MAN 84 (Margaret H. Beigel \& Gertrud M. Kurth, trans., 1941).

144. Id. at 86 .

145. Id. My analysis here is in no way meant to suggest that victims of domestic violence in any way "want" or "ask for" abuse. The fact that power dynamics in relationships are complicated does not excuse or justify violence. I thank my colleague Michael Grynberg for urging me to clarify this point.

146. Bertram H. Raven, et al., The Bases of Conjugal Power, in Power IN Families 217, 218 (Ronald E. Cromwell \& David H. L. Olson, eds., 1975).

147. Id.

148. Madoff, supra note 5, at 622 .

149. For the definitive account of the Johnson \& Johnson case see DAVID MARGOLICK, UNDUE INFLUENCE: THE EPIC BATTLE FOR THE JOHNSON \& JOHNSON FORTUNE 265 (1993). 
Seward Johnson, heir to the Johnson \& Johnson fortune, left most of his estate to his much younger Polish-born third wife, Basia, a former maid in the household. ${ }^{150}$ The Johnson children contested the will, and their lawyer, Alexander Forger of Milbank Tweed, described the alleged inducement of Seward Johnson's will in terms crafted to fit the definition of undue influence:

"[T]he shift of Seward's wealth to Basia... [was] wholly unnatural and contrary to the decedent's lifelong instincts ... free of improper influences, he would never have dreamed of defaulting in his perceived obligation of stewarding his wealth for the benefit of mankind... [Basia] cause[d] him to do that which was totally foreign to his very being."

Indeed, appearances seemed to support her control over him. She was known for her screaming tantrums and tirades, which could go on for hours, and she had been heard to berate and insult him. ${ }^{152}$

Not so fast, testified Dr. Herbert Spiegel, a member of Columbia University's College of Physicians and Surgeons, and a specialist in susceptibility to persuasion. ${ }^{153}$ Appearances were deceiving: Dr. Spiegel testified that to Seward, Basia's screams were "'like water off a duck's back ... [they] didn't mean a thing to him. He was secure about who he was." "154 To the contrary, in fact, the sound of her tirades may very well have sounded "'like music to a man who knows that there is somebody so close to him... [like] [w] hen men in combat hear that artillery blast ... that's like the sound of music.""155 Far from being intimidated by her emotional outbursts, the doctor explained, Seward simply ignored them. What mattered to Seward was control over what interested himhis business and his money. Everything else he left to others because it did not interest him. None of Basia's outbursts threatened what Spiegel called Seward's "main core domain." ${ }^{156}$ As if to underscore the bad fit between psychiatry and the courtroom, the children's lawyers immediately pounced on the artillery metaphor, and the judge mockingly had it stricken, noting that "'the people on this jury, thank God, haven't been subject to artillery blasts."

150. Id. at $263-65$.

151. Id. at 265 (quoting affidavit of Alexander Forger).

152. Id. at 264 .

153. Id. at 575 .

154. Id. (quoting testimony of Dr. Herbert Spiegel).

155. Id. at 575-76.

156. Id. at 575 .

157. Id. at 576 . 


\section{The Myth of the Autonomous Self}

Perhaps an even more profound problem with the psychology of undue influence is the doctrine's reliance on the idea of a stable, independent self with firm and discernible boundaries between itself and others, susceptible to dependence on relatives, but never legitimately on non-relatives. In essence, this notion is that of the liberal self, a notion that arose at a particular time and place to serve the needs of that time, and it is the self that post-structuralist thinkers of the past forty years, in particular Michel Foucault and Jacques Lacan, have robustly challenged. As Melanie Leslie has pointed out, jurors have less trouble seeing this notion of self in the context of family relationships, but have more trouble applying it to interdependent relationships between non-relatives because such relationships often do not fit their own personal experiences. $^{158}$ This is unfortunate, because interdependence, whether among relatives or non-relatives, is the essence of selfhood.

First, the concept of the self as impermeable from without, "free and indivisible," and having its own distinct "will" separable from that of others is the product of a particular time and place, not an eternal truth. ${ }^{159}$ The years 1660 to 1800 in England saw increasing social mobility and the ebbing of prescribed social roles and positions. These social changes required the formulation of the idea that identity is unchanging, untouched by class, history, and gender. ${ }^{160}$ The autonomous, stable self conception responded to the anxieties caused by social flux and indeterminate identity. Descartes was the first important proponent of this concept, paring away sensation, feeling, and any beliefs he was unsure of, finally to locate the stable self, famously, in cognition- "I think, therefore I am." " structure independent of external authority. ${ }^{162}$ This move allowed Descartes to find absolute free will in the human being: "Let everyone just go down deep into himself," he said, "and find out whether or not he has a perfect and absolute will, and whether he can conceive of anything

158. Leslie, supra note 26.

159. See Felicity A. Nussbaum, The Autobiographical Subject: Gender and Ideology IN EIGHTEENTH-CENTURY ENGLAND 56-57 (1989).

160. See id. at 56 (stating "in eighteenth-century England the public struggles over the construction of a coherent, rational, and self-authorizing identity are located in philosophical and religious language to make the individual seem distinct from society and outside of history, blind to class and gender").

161. RenÉ Descartes, Descartes' Conversation with Burman 4 (John Cottingham trans., Clarendon Press 1976) (1691).

162. Id. at $4-5$. 
which surpasses him in freedom of the will."163 The effect of Descartes's analysis was to identify the self as what it thinks, thus equating the self with consciousness. Consciousness, then, became the basis for the self's ideas and values.

Locke was the first to set out the terms of this discussion. In his Essay Concerning Human Understanding, he argued that a person could be the "same man" despite being "beside himself" in states such as senility, madness, or loss of consciousness. ${ }^{164}$ Hume furthered this construction of the self by postulating that character can change and vary without threatening the integrity of identity because character is separate from identity. ${ }^{165}$

These developments in philosophy coincided with a parallel development in the law. As I have shown, the nineteenth century saw an expansion of the undue influence doctrine from its basis in duress to the broader notion involving interference with a person's free agency, and the doctrine was increasingly applied to the aged, infirm or the "submissive." "166 As Professor Dawson puts it, "Inspired by this new conception [of the independent self], the nineteenth century cases seemed to have set off in pursuit of an ideal as attractive as it was unattainable." The ideal was absolute free will. ${ }^{167}$

Post-Freudian psychoanalysis questioned these notions of the self. Jacques Lacan, in particular, building on and revising the works of Freud, posited a self that is much more fragile than the Lockean "same man" tradition suggested because Lacan's self was constituted through intersubjectivity and its relations with others. ${ }^{168}$ Rather than being born with a stable self that somehow possesses its body, Lacan argued that the infant experiences its physical being as vulnerable and fragmented, and only comes to appreciate the possibility of stability, integrity, and wholeness through seeing itself reflected in mirrors and in the people around it-first, from its primary caregiver, and, ultimately, from the

163. Id. at 21 .

164. JOHN LOCKE, AN ESSAY CONCERNING HUMAN UNDERSTANDING 171 (Raymund Wilburn ed., J.M. Dent \& Sons Ltd. 1948) (1690).

165. David Hume, A Treatise of Human Nature 94-106 (L.A. Selby-Bigge ed., Oxford Press 1928) (1748).

166. ARENSON, supra note 119, at 12.

167. Dawson, supra note 1, at 264.

168. Before approaching Lacan, I think, some caveats are de rigueur. To put it simply Lacan is an obscure and difficult writer; some argue that obscurity is the essence of his writing. Some legal academics have partially relieved that obscurity, and I rely on them heavily here. Also, I employ only a small part of Lacanian theory in my analysis here; I limit myself to what is essential in understanding how Lacan's theory of the self affects an understanding of undue influence. 
looks and actions of all those it encounters. ${ }^{169}$ The image of the other thus offers an alternative to the physical experience of fragmentation of the infant's body, and, as such, a fantasy of a "whole, intact, clearly demarcated, and stable self" which gives it a sense of continuity and coherence. ${ }^{170}$ The result is that the infant perceives its body and bodily movements from the outside, either in others or in its own reflection. ${ }^{171}$ Thus, there occurs from the beginning a conflation between the internal sense of identity and the external image, so that the former does not exist independently of the latter. ${ }^{172}$ So, too, with desire. A child is born with unformed desires that give rise to the child's cries, but these desires only find their specific object through perceiving desire enacted in others. ${ }^{173}$

Lacan's theories set forth a full-blown critique of the popular Cartesian subject - in other words, of the stable, autonomous self. ${ }^{174}$ Lacan's self is, rather, a network of relations among the speaking subject, the other people, the subject's recognitions and misrecognitions of itself in those other people, and the subject's unconscious. ${ }^{175}$ Indeed, some scholars claim Lacan's schema of the subject is the basis for a "new science of man," a theory which will "tell the whole story of the mind in action." 176 As Lacan sees it, this intact, stable self is a fiction set over and against the actual physical and emotional disorganization of the body. ${ }^{177}$ It is a necessary fiction, however, because it is the basis on which the self strives to act autonomously and consistently - as if the self were in fact stable and intact. This fiction is thus also necessary for legal consent; indeed, it forms the basis of western notions of the self as legal actor. What is important to my analysis, however, is that this stable, consistent self is a fiction, and does not express the reality of how the self functions or experiences. It overlooks the fact that the self is constituted in relation to others and only strives for autonomy and stability through its contact with those around it.

Lacanian theory is especially suited to cases like In re Will of Kaufmann, which seems designed to illustrate Lacanian notions of the

\footnotetext{
169. Louise du Toit, Conditions of Consent, in CHOICE AND CONSENT: FEMINIST ENGAGEMENTS WITH LAW AND SuBJECTIVITY 58, 66 (Rosemary Hunter \& Sharon Cowan eds., 2007).

170. Id.

171. Mark Bracher, Lacan, Discourse, and Social Change: A Psychoanalytic Cultural CRITICISM 32 (1993).

172. Id.

173. Id. at 33-34

174. See David S. CAudill, Lacan AND the SubJect OF LaW: Toward A PSyChOANALYTiCAl CRitical Legal THEORY 7 (1997).

175. Id.

176. Id.

177. du Toit, supra note 169 , at 66 .
} 
self. Robert Kaufmann famously wrote a letter explaining why he left his estate to his live-in companion rather than to his family. ${ }^{178} \mathrm{He}$ explained:

Walter gave me the courage to start something which slowly but eventually permitted me to supply for myself everything my life had heretofore lacked: an outlet for my long-latent but strong creative ability in painting ... a balanced, healthy sex life which before had been spotty, furtive and destructive; an ability to reorientate myself to actual life and to face it calmly and realistically. All this adds up to Peace of Mind - and what a delight, what a relief after so many wasted, dark, groping, fumbling immature years to be reborn and become adult!

I am eternally grateful to my dearest friend-best pal, Walter A. Weiss. What could be more wonderful than a fruitful, contented life and who more deserving of gratitude now, in the form of an inheritance, than the person who helped most in securing that life? I cannot believe my family could be anything else but glad and happy for my own comfortable self-determination and contentment and equally grateful to the friend who made it possible. ${ }^{179}$

Robert's letter explains how his relationship with Walter literally redefined Robert's "self" in a way that felt more genuine for him. It was not the case that his "old" self was somehow false and the "new" self the "real" one, or vice versa. Rather, the self Robert found through his relationship with Walter was a mode of being which felt more productive and peaceful for him. It allowed him to express his homosexuality by letting him see himself in another gay man, perhaps the first positive "mirror image" he had encountered for this part of his personality. The words "spotty, furtive and destructive" indicate an unrealized, fragmented, and stunted part of the self that blossomed into coherence through contact with Walter. ${ }^{180}$ It is not surprising that Robert said he had been "reborn and become adult," 181 finding images in others that shape one's sense of self is integral to a child's psychic growth. Even the seemingly redundant phrase "dearest friend-best pal" Robert used to describe Walter seems syntactically designed to emphasize this mirroring. ${ }^{182}$ The fact that Robert's "new" self was no more "real" than his "old" self is clear from his sudden hardheaded swerve back into the world of money and business apparent in his statement that Walter

178. In re Will of Kaufmann, 247 N.Y.S.2d 664, 671 (N.Y. App. Div. 1964).

179. Id.

180. Id.

181. Id.

182. Id. 
deserved the inheritance as a form of repayment for the life he allowed Robert to have. ${ }^{183}$

What this case and other undue influence cases show is that what we call the "real" self and its "real" intent are all forms of a fiction constructed through relationships with others, and labeling some of them genuine and others false fails to account for this process. There are, of course, other kinds of undue influence cases, as I have shown, where elders leave money out of gratitude to a non-relative who helped them. What I wish to emphasize here is that the theory on which the doctrine is based is fallacious, and cases like Kaufmann highlight its fallacy.

Post-structuralism has also undermined the idea of the written and executed will as expressing its author's true intent in another way, through what Foucault calls the "author function."184 Foucault argued that a text is as much a result of the language it deploys as it is of the author's intent. ${ }^{185}$ Put another way, he claims that the writing subject is as much produced by-he says, "subjected to"- the meaning that language, and by extension, culture, legitimizes for the particular form in which he is writing. ${ }^{186}$ To be sure, the subject is also an agent, intending to communicate, but it is simultaneously constrained by the effect of culture and language on its expression. ${ }^{187}$ These constraints are especially present in the case of wills, where one of the functions of the formalities required to execute a will is the "channeling function," which requires the testator to shape his testamentary desires into "conventional and unmistakably expressed" terms, thereby creating "uniformity in the organization, language, and content of most wills." "188 This, in turn, allows the probate court to "process his estate routinely," reducing the cost of judicial administration. ${ }^{189}$

Thus, the will, as a writing, expresses the "author function" as opposed to "the author." Foucault's question is whether a will - or any form of legal writing - ever represents a true "self," constrained as it is by the formalities and limitations on that particular form of writing. Wills, which the law seems to regard as especially expressive of personal desires, but which are constructed at a nexus of social roles and

183. Id.

184. Michel Foucault, What is an Author?, in Language, Counter-Memory, Practice 124, 124-27 (Donald F. Bouchard \& Sherry Simon trans., 1977).

185. Id.

186. Id.

187. Id.

188. John H. Langbein, Substantial Compliance with the Wills Act, 88 HARV. L. REV. 489, 494 (1975).

189. Id. 
expectations and with very strict linguistic requirements, make this issue especially pertinent - and poignant. Put simply, when one sits down to write a will, one's wishes are channeled into very narrow modes of expression, and one faces the traditions and expectations of this particular form of writing. A drafting attorney will probably assume traditional dispositions, and express surprise, at the very least, at any contrary inclinations. More than that, however, the expectations created by the ceremony of will drafting and the language of the text itself channel what may be a range of amorphous emotions and desires into conventional channels.

\section{B. Doctrinal Problems}

Seventy years ago, an article challenged the notion of "free agency" in undue influence cases by asking:

What would a man do 'if left to himself'? Surely he would not make a contract or a gift, for by hypothesis there would be no promise or donee. The attempt to solve legal problems ... by postulating an individual will insulated from its social environment, only serves to obscure the genuine problems of ethics and policy.... The whole régime of property ... is a system of legitimized coercion. ${ }^{190}$

The author goes on to acknowledge that no clear line exists between pressure and no pressure, but only between "permissible and nonpermissible" forms of pressure. ${ }^{191}$ This articulation expresses the dilemma of undue influence in its common law form: no transaction, no act at all, is free from some kind of influence, and seeking to isolate one person's will from another's is a futile endeavor. ${ }^{192}$ As discussed, Swinburne made the same point centuries earlier, and long before him, so did Aristotle. ${ }^{193}$ Having reframed the question in a way that makes it impossible to answer, how do law courts analyze it?

\section{Vagueness Creates an Opening for Ideology}

The doctrine's vagueness leaves it at the mercy of the ideological forces in play in a culture at any given time. Arguably, ideology, as a

190. Edwin W. Patterson, Compulsory Contracts in the Crystal Ball, 43 Colum. L. REv. 731, $741-42$ (1943).

191. Id. at 742 .

192. Id.

193. See supra notes $45-48,54$ and accompanying text. 
false version of reality, is always present in culture, but its nature and effect can be more or less extreme. Slavoj Zizek shows how, at its most extreme, ideology takes even those aspects of reality which seem most obviously to contradict it, and interprets them as confirmation of its worldview. ${ }^{194}$ Thus, Zizek argues that ideology cannot be cured by simply peeling away the false representation from real facts. He offers an example from 1930s Germany, where the fact that a Jewish person was not dirty, conniving, and dishonest served simply to reinforce National Socialism's anti-Semitic fantasy because it was "interpreted" to show how dangerous Jews really were, and how cleverly they could hide their true nature and disguise themselves to appear like everyone else. ${ }^{195}$ The appearance of this tendency in the law is surely a sign of a doctrine that is seriously dysfunctional. Kaufmann exhibits legal reasoning that seems to embody exactly this function of ideology: the more the decedent tried to make clear his trust and affection for the proponent and his sincere desire to benefit him in his will, the less willing the court was to believe it. ${ }^{196}$ Although criticism of the Kaufmann decision is legion, no one has discussed the implications of the role of ideology in the court's analysis.

The court, upholding the jury's finding of undue influence, held that Robert's letter was "cogent evidence of [the testator's] complete domination by Weiss. Its exposure, implications and distortions can be understood only as an attempt to justify what is obviously unnatural and utterly inconsistent with reality and what the record establishes was the warm and close relation between Robert and his family."197 It seems clear that the court's use of the words "exposure," "implications," "distortions," and "unnatural" refer indirectly to what really motivated the court's decision - its distaste for Robert's homosexuality, and its sympathy for the family's double injury in being disinherited by a bequest to his male lover and the resulting "exposure" of his "unnatural acts" to the public eye.

Because ideology is immune to reality in a case like this, Zizek argues, it is necessary to seek instead the desire, or unconscious wish, that makes the ideology necessary in the first place. ${ }^{198}$ In 1930 s

\footnotetext{
194. CAUDILL, supra note 174, at 124. The classic example of this working of ideology with respect to law occurs in Charles Dickens's Bleak House, in which the young Richard Carstone puts more and more money, energy, and emotions into his legal battle, interpreting each example of its hopelessness as a sign of progress. Id. at 125-27.

195. Id. at 123-24.

196. See In re Will of Kaufmann, 247 N.Y.S.2d 664, 681-82 (N.Y. App. Div. 1964).

197. Id. at 684 .

198. CAUDILL, supra note 174, at 125.
} 
Germany, the desire was for a perfectly homogeneous community. Because this fantasy is unachievable, an ideological distortion of reality is necessary to simultaneously affix blame for the fantasy's failure and to identify the impediment to its realization. ${ }^{199}$ In Kaufmann, the unconscious desire may have been to deny the existence of homosexuality in general and a homosexual relationship between Robert and Walter in particular. This unconscious wish is immune to reality: it will distort any reality to fit its needs. ${ }^{200}$ Thus, nothing Robert said could have proved lack of undue influence; the more convincing his statements to this effect appear to be, the more the court will read them as proving their opposite.

Unfortunately, this is not an isolated case. In Huguenin v. Baseley, the court concluded that evidence that "the person was perfectly aware of what he was doing; and had repeatedly confirmed it ... only tends to shew more clearly the deep-rooted influence, obtained over him." ${ }^{201}$ The consistency of a bequest with an established overall estate plan "prove[s] nothing," said another court, "for the same power which produces one produces the other; and therefore, instead of removing such an imputation, it is rather additional evidence of it." ${ }^{202}$ Again, in the Lakatosh case, with which this Article began, the judge observed that a tape recording made by the attorney who drafted Rose's will contained "several comments ... which indicate she had a weakened intellect and that she was somewhat out of touch with reality," specifically, Rose's reference to Roger as "'an angel of mercy,' who had 'saved her life' because, before she met him, she had been 'so low in hell."”203 The court took these remarks as evidence that the bequest to Roger could not have been a product of her own free will, yet it seems like a reasonable statement from an elderly woman who had been abandoned by her family and had found someone to help her with chores and errands that she could no longer do herself. In cases involving elderly testators who leave their estates to non-relatives, courts seem to be pursuing the fantasy that we live in a world in which children take care of their aging parents rather than abandoning them, and denying the reality that the strangers who care for them, whether out of pecuniary motives or not, may be providing an important service and may be the best friends many elderly people have. They may also be partaking of a national fantasy that we

\footnotetext{
199. Id.

200. Id.

201. Huguenin v. Baseley, (1807) 33 Eng. Rep. 526, 531 (Ch.).

202. Bridgeman v. Green, (1757) 97 Eng. Rep. 22, 27 (K.B.).

203. Estate of Lakatosh, 656 A.2d 1378, 1385 (Pa. Super. Ct. 1995).
} 
do not live in a society that sometimes ignores and abandons its elderly to poverty and isolation.

Finally, Kaufmann reveals how the fluidity of the undue influence doctrine allows its application to express the free-floating anxieties of a particular era. In Kaufmann, the court faced a man clearly expressing his wishes to do something which the court nonetheless deemed fundamentally opposed to his nature and true inclinations. This conundrum - that someone could be brainwashed into earnestly wishing to do something completely antithetical to the person's nature-was part of the contemporary discourse of the Communist threat and the fear of brainwashing. In 1962, the film The Manchurian Candidate raised this very question in its opening scene. The Russian and Chinese hypnotists showcase their experiment on the captive Laurence Harvey to prove that brainwashing, long considered impossible, can, in fact, be done. ${ }^{204}$ Indeed, "[h]is brain is washed of all natural desires and loyalties and set like a timebomb to perform assassinations for the Communist cause." ${ }^{205}$ The ultimate threat of Communism is that it "is the fatal usurper. It displaces family love and outrageously makes political belief stronger than natural affection and honest sex."206 This interpretation at least reveals the logic in the court's seemingly perverse analysis of Kaufmann's statements. The more stridently he insisted on his emotions, the more suspect they became; passionate expressions of feeling were unreliable in a world where hypnosis could program men to strangle their comrades.

At its core, Kaufmann showcases competing notions of selfhood. As Robert put it, Walter gave him access to a selfhood that felt more genuine and innate-"natural"- than the selfhood he had experienced before. $^{207}$ This process is much like that of psychotherapy; in fact, Robert's letter reads like an expression of gratitude to a longtime therapist. The Kaufmann court had a narrow definition of what autonomy in Robert's case would have meant. The court stated that

if Weiss had aroused in Robert a drive for independence, had persuaded him to inform himself and assume the right to make his own decisions in matters of business and otherwise, there could be no objection even though Robert saw fit to be advised by Weiss. However, if Robert was unwilling or unable to assume responsibility in financial and other

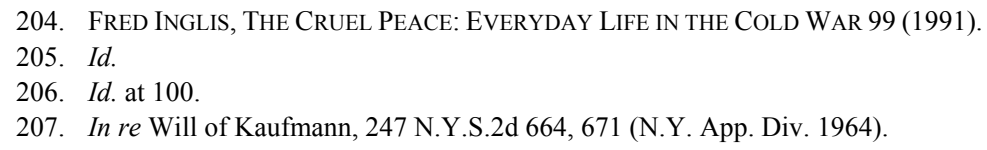


matters, and Weiss was aware of it and using Robert against... his family to further his own selfish ends and purposes

then the question of undue influence arises. ${ }^{208}$ The use of the phrase "other matters" is notable, for indeed, it is precisely in respect to "other matters" - namely, his sexuality and vocation - that Walter did awake in Robert the will to make his own decisions. But this is clearly not what the court had in mind. Autonomous decision-making is linked to business and financial planning and other pursuits linked with capitalist individualism, not sex and creativity - arenas where the separation of the subject from others becomes blurred. Again, the court observed that when Robert's financial records were transferred from Washington to New York, where he lived, shortly after he had "taken up" with Weiss, there was "no reality to support [these] changes" because Walter had no qualifications in finance and because it made no sense to transfer the records from the center of the family's business. ${ }^{209}$ The court's version of reality fails to encompass Robert's emotional reality because the court's understanding of an autonomous self is defined in terms of entrepreneurship and capitalist enterprise.

This section has indicated why the revisions to the Restatement fail to address the core problems with undue influence. The comments to section 8.3 say that a testator's "domestic partner" and a "donor's unmarried partner" in a civil union are "as much a natural object of the testator's bounty as a donor's spouse." 10 While this indicates a development in social norms that are increasingly accepting of nontraditional relationships, by that very fact it does little to advance the cause of testamentary freedom, which is needed not to protect accepted relationships which juries can relate to based on their own lives, but rather precisely those which are excluded from social acceptance. Simply by widening its net of acceptability to gather in more relationships, the Restatement does little to protect those bequests which are most in need of its protection.

\section{Bad Decisions Continue}

The history of undue influence cases contains many examples other than Kaufmann of what most today would call serious miscarriages of

\footnotetext{
208. Id. at 669 .

209. Id.

210. Restatement (Third) OF Prop.: Wills and Other Donative Transfers $\S 8.3 \mathrm{cmt}$. $\mathrm{f}$ (2001)
} 
justice. $^{211}$ Readers might assume that such travesties are products of the social prejudices of former times, and that such miscarriages are a thing of the past in today's enlightened courts. This is not the case. Rather, recent cases prove that the vagueness of the undue influence doctrine still leaves the door open to courts imposing their ideology-driven views of morality and propriety upon the will of the testator. One such case is In re Estate of Reid, decided by the Supreme Court of Mississippi. ${ }^{212}$

Mary Lea Reid, a seventy-eight-year-old widow, had been befriended by - or had befriended-Michael B. Cupit. He was a twentyfour-year-old man, the court noted disapprovingly in the first sentence of the opinion, who had shown up to view Reid's antebellum home in Brookhaven, Mississippi. ${ }^{213}$ The two remained friends and saw each other frequently until Reid died; she adopted him and executed a deed and a will in his favor. ${ }^{214}$ A "potential heir" challenged these transfers as products of Cupit's fraud and undue influence. ${ }^{215}$ The court agreed, and went through numerous legal and verbal contortions to invalidate the adoption, the deed, and the will, ignoring the applicable statute of limitations to do so. ${ }^{216}$

The opinion made clear that the court disapproved of Reid's relationship with Cupit, despite her apparent pleasure in it. It quotes a "friend and relative" of Ms. Reid as saying that "she was very embarrassed by [the] relationship, especially their physical affection toward one another." ${ }^{217}$ The court refers to letters from Reid to Cupit indicating "an intimate relationship of some nature," but never specifies the kind of intimacy involved. ${ }^{218}$ The court filings, however, tell a different story. Asked during deposition whether Cupit "unduly influenced or ... compelled" her to deed her land to him, Reid burst out "[o]h, that makes me fighting mad. The fellow that said that, I'd like to choke him, because that's a lie. He better go home and get down on his knees and ask God to forgive him.... That's just not right."219 Witnesses testified that Reid adopted Cupit due to her "strong desire to

211. See, e.g., In re Will of Moses, 227 So. $2 \mathrm{~d} 829$ (Miss. 1969); Latham v. Father Divine, 85 N.E.2d 168 (N.Y. 1949).

212. 825 So. $2 \mathrm{~d} 1$ (Miss. 2002).

213. Id. at 3 .

214. Id. at 3-5.

215. Id. at 3 .

216. Id. at $5-8$.

217. Id. at 3 .

218. Id.

219. Brief of Appellant at 1, In re Estate of Reid, 825 So. $2 d 1$ (Miss. 2002) (No. 2000-CA00663), 2000 WL 34429803. 
have a child which she had never had," that Reid "was proud to have Cupit as her adopted son and heir,"220 and that she told everyone in the community that Cupit was "a good son to her.",21 The court approvingly notes the trial court's disregard and discrediting of this evidence, however, saying "the chancellor [below] found that this testimony must be seen in the proper context. Those witnesses did not have the benefit of knowing the whole story"222 - a "whole story" apparently, the court knew better than those who knew Reid and had witnessed the relationship, and which it eagerly supplied:

The Court finds that the evidence regarding []Cupit's efforts to exclude most, if not all of the family members and some long-time friends of Mary Reid from her, together with Mary Reid's strong desire to have a child which she had never had, coupled with the engaging and unique personality and tendencies of []Cupit ... combined so as to put Mr. Cupit in a position with Mary Reid that Mr. Cupit could and did overreach and influence Mary Reid to his advantage and her ultimate disadvantage. ${ }^{223}$

There was no question that Reid had capacity and the evidence seemed to show, moreover, that she had had independent legal advice and consultation in executing the documents at issue. ${ }^{224}$ Although Cupit arranged meetings with a judge and an attorney concerning the adoption, Reid also met with counsel without Cupit present. ${ }^{225}$ Indeed, at their second meeting, counsel dissuaded Reid from going forward with the adoption, whereupon Reid asked him to draft a deed conveying her property to Cupit. ${ }^{226}$ In a classic rhetorical pattern of undue influence cases, the court found Reid's consistency in this regard not to evidence her intent but rather the lack thereof. ${ }^{227}$ To avoid the implication that she had received independent advice by meeting privately with her attorney, the court declared that, in fact, "Cupit was [the client] and that the contact between Cupit and [the attorney] was more substantial than" that between the attorney and Reid. ${ }^{228}$ The court acknowledged that in a later meeting to draft her will, "[Cupit] did not participate in the discussion,"

220. Reid, 825 So. $2 \mathrm{~d}$ at 4 (emphasis added).

221. Brief of Appellant, supra note 219, at 12.

222. Reid, 825 So. $2 \mathrm{~d}$ at 4.

223. Id.

224. Id.

225. Id. at 3-4.

226. Id. at 4 .

227. Id. at 6 .

228. Id. at 4 . 
and the attorney "took every precaution to ensure that she was competent and that no overreaching was involved."229 The court answers this objection, though, by smugly observing that "there was undue influence and overreaching arising from 'antecedent circumstances' of which [the attorney] could not be aware." 230 With the possibility of such "antecedent circumstances," of course, it would never be possible for independent legal advice to validate any transfer attacked on undue influence grounds. Finally, the court blithely mentions evidence that Reid was "strong willed," only to brush it aside and declare that undue influence existed "notwithstanding" such testimony. ${ }^{231}$

In short, the court was hell bent on invalidating the will and deed and allowed neither facts nor law to get in its way. In addition to distorting evidence, the court misstated the law to reach the desired result. Despite a ten-year statute of limitations on actions to recover land, the court found a loophole "where there has been concealed fraud in the conveyance," thus allowing the statute of limitations to begin to run upon the discovery of the fraud. ${ }^{232}$ The only trouble is the allegation was undue influence, not fraud, with respect to Reid's conveyance of land to Cupit. My point, however, is not to show lacuna in the reasoning in these cases. That courts routinely ignore testamentary freedom to impose social norms and moral judgments on testators' decisions, that women in relationships with younger men are more likely to have their wishes ignored than men with younger women, that devises to others than relatives are likely to be deemed results of undue influence despite extensive evidence of capacity and independent decision-making, other scholars have proved before. ${ }^{233}$ Rather, that such violations of testamentary freedom continue to occur together with the other arguments made here supports my contention that the doctrine should be abolished.

A final point about Reid. The Mississippi Supreme Court approved the lower court's finding that Reid's adoption was the "product of 'long term plan and scheme' concocted ... by fraud and overreaching."234 This assertion might be subject to argument, but the real question I wish to raise is, what of it? Would a "long term plan or scheme" invalidate the pride and enjoyment her friends testified Reid felt in the relationship?

233. See sources cited supra note 5 .

234. Reid, 825 So. $2 \mathrm{~d}$ at 7. 
Why is it impossible that one can only exist without the other? As I have argued, individual will is inseparable from the will and actions of others around it. Based on such a paradigm, it seems perfectly plausible that Cupit could have "planned and schemed" to acquire Reid's property in a way that made the widow wish to benefit him of her own free will. It is hard to imagine a court chastising a child for returning home to tend to an aging parent in a plot to inherit the estate. Indeed, as I show below, courts routinely find in favor of such beneficiaries. Like the court in Reid, courts and juries, in general, fail to recognize the relational self outside of the family context, or, at least, relationships which do not find analogs in their own lives. ${ }^{235}$

Other courts have put on similar blinders. In 1991, Evelyn Afton Maheras died testate, leaving the bulk of her estate to the First Baptist Church of Bartlesville, Oklahoma. ${ }^{236}$ Her nephew and sole heir challenged the will on capacity and undue influence grounds, among others. ${ }^{237}$ Although finding that Maheras had testamentary capacity, the court found that the church's pastor, despite the fact that he did not personally benefit from the will, had nonetheless exercised undue influence over Maheras and affirmed the trial court's order denying the will probate. ${ }^{238}$ The record revealed that the testator was an alcoholic whose health and living conditions deteriorated in the $1970 \mathrm{~s}$, but that in 1980 she became acquainted with the pastor and several members of First Baptist, some of whom cleaned her house on a regular basis. ${ }^{239}$ The record contains no mention of the nephew helping her in any way; she seemed to have been on a downward slide until the church members came along. ${ }^{240}$ Her fellow church members' help and friendship make it at least reasonable that she would have left her estate to them. The fact that the lawyer who drafted her will discussed its terms with her on two separate occasions and that the witnesses testified that she understood the will and was aware of her nephew's existence makes the devise seem all the more reasonable.

Yet, the court found undue influence. ${ }^{241}$ The court seemed disturbed by the fact that the lawyer who prepared the will and the witnesses were all church members, ${ }^{242}$ but this hardly seems dispositive. After years of

235. Leslie, supra note 26.

236. In re Estate of Maheras, 897 P.2d 268, 270 (Okla. 1995).

237. Id. at 271 .

238. Id. at 274 .

239. Id. at 271 .

240. Id.

241. Id.

242. Id. 
alcoholism and physical decline, it may have been that Maheras simply did not have a wide social circle to call on. ${ }^{243}$ Moreover, it seems likely that the will reflected her gratitude to the institution that had retrieved her to some extent from the state she was in, and lack of gratitude to her one heir who apparently did little to help her. Why then, is it obvious that the Church "was not a natural object of her bounty"? ${ }^{244}$ The Court correctly cites the law in this regard - that the natural object of a testator's bounty is one related by blood-but this case highlights the illogic of this maxim. ${ }^{245}$ What more natural "object of bounty" could there be than the community that cleaned her house and gave her companionship for the last fourteen years of her life? Surely the only stretch would be to say that it should be the nephew, whose first appearance was to contest the will.

A 1989 case from Montana shows how facts in undue influence cases are susceptible to completely valid conflicting readings. The majority in Christensen v. Britton, reversing a bench trial below, paints a tragic picture of an elderly man, distraught after the loss of a beloved wife, being stripped of his goods and savings by unscrupulous fortune hunters. ${ }^{246}$ For example, the majority tells us the donor deeded his house to one of the defendants, who then asked him to leave, as a result of which he "was forced to leave the home he had occupied for over thirty years. ... [and] was not allowed to take any of his personal possessions," which had also been conveyed to a defendant. Furthermore, his poor eyesight made him dependent on others which in turn "made him susceptible to overreaching." "247 It is left to the dissent to tell us that the donor deeded his property to defendants as a well-thought out decision to avoid a will contest by his children (one of whom, indeed, was the plaintiff in the case), that he left his residence of "over thirty years" because he had bought a new house to move into, and that he himselfstill alive at time of trial — did not testify that he had been under any kind of coercion or undue influence when he made the gifts. ${ }^{248}$

Similarly, in In re Estate of Waters, the decedent's daughters contested a will leaving the decedent's estate to his fourth wife to whom

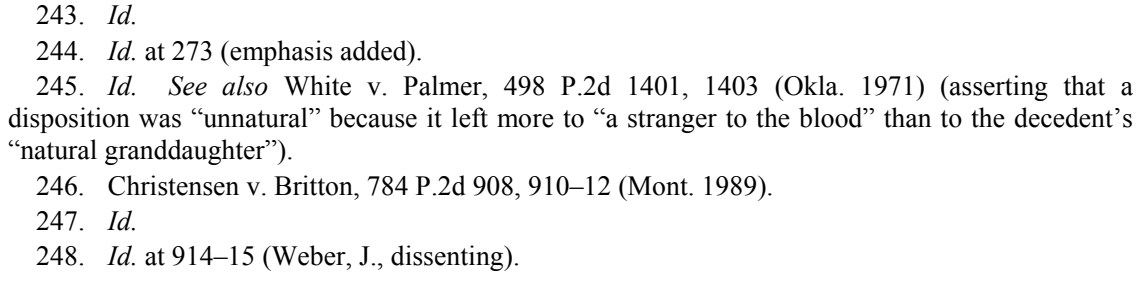


he had been married six weeks. ${ }^{249}$ The court agreed with the jury that the testator, debilitated by alcoholism, had not lacked capacity, but that he had been influenced because his wife was in the habit of bringing him alcohol, she had accompanied him to the attorney's office to have the will drawn, and the attorney had never talked to him without his wife present. ${ }^{250}$ The court held that "[i]t would be fair to say, therefore, that the testator was completely dependent upon [her] and that he was completely under her domination at the time of the execution of the will." 251 The dissent pointed out, however, that this was perfectly normal behavior between husband and wife, as was the disposition itself, and quotes the wife's testimony that she brought the testator alcohol only after "I cussed, and I cried, and I bawled, and I stompted, [sic] and it done no good. He still had to have a drink no matter what I could do. All the tender-loving care there was, I couldn't keep him from drinking. ${ }^{, 252}$

Finally, in In re Will of Ferrill, a New Mexico court affirmed the invalidation of a will that left the testator's estate to the couple who had cared for her in the last months of her life as she was dying of cancer and disinherited her family. ${ }^{253}$ Strangely, one of the reasons for invalidating the will was that decedent "trusted []and thought very highly of" the beneficiaries who "devoted much time and attention to" her when her family, apparently, did not. ${ }^{254}$

\section{THE COSTS OF CONTINUED UsE}

The continued use of this doctrine entails significant costs. The number of contested wills is increasing, and the most common method for contesting a will is an allegation of undue influence. ${ }^{255}$ On the one hand, the continued existence of the doctrine encourages numerous

\footnotetext{
249. In re Estate of Waters, 629 P.2d 470, 472 (Wyo. 1981).

250. Id. at 473 .

251. Id.

252. Id. at $476 \mathrm{n} .1$ (Rooney, J., dissenting)

253. 640 P.2d 489, 492 (N.M. Ct. App. 1981).

254. Id. at 493 .

255. Bonfield supra note 97, at 1909; Jeffrey A. Schoenblum, Will Contests-An Empirical Study, 22 Real Prop. Prob. \& Tr. J. 607, 647 (1987). See also Eunice L. Ross \& Thomas J. ReID, WILL CONTESTS $§ 7: 21$ (2d ed. 1999) (stating that "undue influence is the most commonly asserted ground for invalidating a will"); Nicole M. Reina, Note, Protecting Testamentary Freedom in the United States by Introducing into Law the Concept of the French Notaire, 46 N.Y.L. SCH. L. REV. 797, 798 (2003) (noting that undue influence has largely swallowed the doctrines of fraud and duress in will contests because it "is far easier to prove and does not require any direct evidence of malfeasance by (or on behalf of) the named beneficiary").
} 
frivolous cases, often brought by one sibling against another who cared for an aging parent and then received a larger portion of the estate. In these cases, courts show awareness that the dependent testator is capable of having testamentary intent, ruling against the contestant on the grounds that the parent had wished to reward the caretaking sibling. Such cases waste the court's time. Second, the continued application of the doctrine creates wasteful litigation costs because heirs discontented with a will can use the threat of a will contest to force a settlement, which often distorts the decedent's intent and depletes the value of the estate.

\section{A. Frivolous Cases and Baseless Strike Suits}

There are cases in which a proponent is able to overcome the presumption of undue influence by convincing the fact finder that the testator had formed a quasi-familial relationship with the beneficiary that superseded the testator's relationship with the challenger. ${ }^{256}$ Such cases indicate that courts are able to see that autonomy does not preclude interdependence with non-relatives. Many of these-but by no means all - concern wills contested by estranged family members offended by the decedent leaving the estate to a faithful caretaker, close friend, or more attentive sibling. These kinds of cases waste the court's time because they are rarely successful. Melanie Leslie's study of the cases cited under West's "key number" for wills over six years found that out of seventy will contests between people who were related to the testator in substantially equal degrees, only eighteen were denied probate. ${ }^{257}$

A good example of this kind of case is Vaupel $v$. Barr, in which the decedent's son and two grandsons contested her will, which left the bulk of her estate to her attorney and long time friend, Don Barr. ${ }^{258} \mathrm{Mr}$. Barr had been taking care of many aspects of Mrs. Vaupel's business and affairs for several years, and had increased his help and support after she had entered a care facility. The lawyer who drafted the will "stated that Mrs. Vaupel told him that Mr. and Mrs. Barr were the only people in her family who visited and cared for her." "It made sense, the court noted, that she left him the estate rather than "family members with whom she had very limited contact." 260

256. I thank Melanie Leslie for helping clarify this point.

257. Leslie, supra note 5, at 244 n.42 (1996).

258. 460 S.E. $2 d$ 431, 433 (W. Va. 1995).

259. Id.

260. Id. at 434-35. 
In a similar case, a son who had been estranged from his father challenged a will that left the estate to his father's girlfriend and caretaker on undue influence grounds. The son appealed when the trial court found no undue influence. ${ }^{261}$ While the father and son were estranged, the girlfriend cared for the decedent (who was ill with the effects of acute alcoholism), saw him every day, cleaned his house, and took him to doctor's appointments; in fact, the two had planned to marry. ${ }^{262}$ "The evidence... is legion," the court observed, "that Jerry exhibited independent consent and action, and that the second will represents his final wishes ...."263 In short, the opinion makes clear that there was little basis for the suit in the first place, much less for the appeal. $^{264}$

In In re Estate of Unke, a daughter appealed a trial court's finding that her mother's will, leaving half the estate to her brother outright while putting the daughter's half in a trust, was not the product of the son's undue influence. ${ }^{265}$ In fact, the daughter was an alcoholic and spendthrift who the mother had feared would exhaust the inheritance leaving nothing for her granddaughters. ${ }^{266}$ There was unremitting testimony that the mother was anything but physically or mentally weak: she "was competent and completely capable of making her own decisions;" she "was not susceptible to influence;" and she "demonstrated business savvy until the time of her death." 267

In another case, grandchildren who had moved away from home contested a deed to the younger son who "lived near his mother and cared for her in a number of ways. He provided her with financial assistance.... He opened his home to her... provided her with assistance in handling her affairs ... and he provided transportation for her to various places and functions." 268 The brother, whose children contested the deed, on the other hand, "had lived in Georgia and had not participated directly in his mother's day-to-day care in Alabama.... $[\mathrm{H}]$ is periodic visits with Ms. Wilson were short."269 In other words, there was nothing on which to build an undue influence case because the

\footnotetext{
261. In re Estate of Saucier, 908 So. $2 \mathrm{~d} 883,885$ (Miss. Ct. App. 2005).

262. Id.

263. Id. at 888 .

264. See id. ("The evidence sub judice is clear and convincing in establishing that Tatum did not substitute her will for Jerry's, and any presumption to the contrary is clearly rebutted . ....")

265. 583 N.W.2d 145, 146-47 (S.D. 1998).

266. Id.

267. Id. at 149 .

268. Wilson v. Wehunt, 631 So. 2d 991, 994 (Ala. 1994).

269. Id.
} 
conveyance was a just result of the mother's different relationships with her two sons. ${ }^{270}$ Other cases have led to similar results. For example, when an immigrant from the Philippines left "his modest property" to a friend and long-time employer, ${ }^{271}$ his relatives, still living in the Philippines and out of contact for years, showed up to contest it, claiming undue influence. ${ }^{272}$ The court noted that the testator may have been "estranged by inattention," and warns, in a footnote, that "attention, as the elderly have little else . . is near everything." 273 In yet another case, the niece of a testator challenged a will on undue influence grounds because it named a close friend as principal beneficiary. ${ }^{274}$ The decedent and donee were "constant companions" who ate, traveled, and spent time together, ${ }^{275}$ by contrast, the testator "saw his niece and nephew very infrequently and only rarely spoke with them on the phone." ${ }^{276}$ The court observed that "influence gained by years of mutual affection is not sufficient in law to establish undue influence."

These cases suggest that some fact finders understand that interdependence between the testator and a non-relative does not necessarily mean loss of autonomy and testamentary freedom.

270. For an analogous case see also Norton v. Norton, 672 A.2d 53, 55 (Del. 1996) (stating that such a will "reflected 'logic — not undue influence").

271. In re Estate of Obra, 749 P.2d 272, 273 (Wyo. 1988).

272. Id. at 277 .

273. Id. at 277 n.9.

274. In re Estate of Weir, 475 F.2d 988, 990 (D.C. Cir. 1973). Examples proliferate, see, e.g., Abel v. Dickinson, 467 S.W.2d 154, 157 (Ark. 1971) (upholding bequest to friend over a brother's protest of undue influence because it was obvious that "these two ladies shared a warm affection for each other"); In re Estate of Robinson, 644 P.2d. 420, 426 (Kan. 1982) (holding that "lawful influence, such as that arising from legitimate family or social relations [in this case, between spouses], must be allowed to produce its natural results, even in influencing last wills"); Sweeney v. Eaton, 486 S.W.2d 453, 455 (Mo. 1972) (denying challenge by testator's dead husband's relatives when testator left her estate to a friend who visited her two or three times a week, took her for drives, and visited on holidays); In re Estate of Holcomb, 63 P.3d 9, 22 (Okla. 2002) (finding trial court's conclusion of lack of undue influence not against the evidence when decedent had intended "to leave her entire estate to [one child rather than others] in gratitude for [the child's] caretaking and because she feared more for [that child's] financial security than for that of her other kin"); Casper v. McDowell, 205 N.W.2d 753, 759 (Wis. 1973) (finding no undue influence when a father left his estate to a friend and housekeeper rather than to his sons who had little contact, and one of whom visited his father's town every year without contacting his father); Mercado v. Trujillo, 980 P.2d 824, 826 (Wyo. 1999) (upholding a will disinheriting some children where the drafting attorney met with the decedent alone, the decedent had written a letter explaining the disposition, and the drafting attorney testified that decedent "knew exactly what she was doing"); In re Estate of Brosius, 683 P.2d 663, 666 (Wyo. 1984) (noting that a will contestant alleged "no facts to counter [proponent's] testimony that she did nothing to encourage [the testator] to make a will or to leave his property to her").

275. Weir, 475 F.2d at 990 .

276. Id. at 992 .

277. Id. 
Unfortunately, as long as the doctrine exists such scenarios will offer a basis for threats to start costly litigation, and a variety of incentives for doing so exist which have nothing to do with the merits of the case. As John Langbein found important, in his review of the book about the Johnson \& Johnson case, the children-contestants' lawyers "'must have known ... that the children could never actually win their case; the object had to be settlement.",278 One reason strike suits are often successful is that, because undue influence and lack of capacity are often intertwined, such claims entail the risk that a trial would expose the testator's every eccentricity and tarnish his reputation. ${ }^{279}$ Another is the fact that, unlike the European or English legal system, the American system submits will contests to trial by jury. ${ }^{280}$ Such a system, Langbein argues, "invites [will contests] ... in which the strategy is to evoke the jurors' sympathy for disinherited offspring and to excite their likely hostility toward[] [the] devisee." 281 Few proponents would choose to expend the time and money hoping that a court would see the truth of the relationships in question when a settlement would be easier and less costly. ${ }^{282}$ The settlement, in turn, would achieve to some degree what the lawsuit set out to do: revise the testator's will in favor of the challenger, thus retaining the doctrine's ability to undermine testamentary freedom.

\section{Policy Concerns ARe AMENABle to Other Doctrines}

So far I have argued that because the doctrine of undue influence fails to protect testamentary freedom and generates significant costs, we should abolish it. In this section, I show that less problematic doctrines more effectively address the concerns undue influence purports to address: coercion and overreaching, especially with respect to the elderly; protection of intended beneficiaries; and reassurance for a testator worried that future decline might leave her vulnerable to failing those she intended to benefit.

278. Langbein, supra note 5, at 2043 (quoting MARGOLICK, supra note 149, at 198).

279. Scalise, supra note 108, at 100.

280. Langbein, supra note 5, at 2043. Not all states allow for jury trials of will contests. 2 PAGE ON THE LAW OF WiLls $\S \S 26.85-26.86$ (rev. ed. 2003). See also H.F.H., Annotation, Right to Jury in Will Contest, 62 A.L.R. 82 (1929).

281. Langbein, supra note 5, at 2043. See also Note, supra note 5, at 95 (observing that "[f]ew questions are less well suited to the determination of a jury than testamentary capacity and undue influence").

282. Ronald Chester, Should American Children Be Protected Against Disinheritance?, REAL PROP. PROB. \& TR. J. 405, 427 (1997) (observing that "suits brought under . . . vague doctrines [like undue influence] tend to settle to avoid costly litigation"). 
These are all parts of one dilemma-how best to protect and effectuate the testator's intent. So far I have shown that undue influence does not efficiently achieve this goal in any of the permutations mentioned. In this section, I argue that other doctrines and public policies can do so more effectively. These doctrines are capacity, duress, fraud, and tortious interference with expectations.

\section{A. Capacity}

Testamentary capacity, or lack thereof, is much easier to prove than undue influence, and would resolve many a will contest. The two doctrines - testamentary capacity and undue influence - are often linked in petitions because a lack of capacity suggests susceptibility to influence. If undue influence were unavailable, however, these cases would be decided on capacity alone, which, as I have suggested, would sufficiently address the cases in which the will should be invalidated. The doctrine of testamentary capacity would address many of the undue influence cases in which the outcomes seem unfair. These cases do not need an undue influence claim to be resolved. Once the capacity issue has been decided in the negative, there is no need to address the question of undue influence.

As an added precaution, antemortem capacity determinations are very often effective in preventing will contests. ${ }^{283}$ As such, they are an underused estate planning device, but could provide reassurance to a testator that her wishes will be carried out. ${ }^{284}$ For example, in In re Estate of Schot, a nephew contested the will of his elderly aunt, who left a large bequest to the care facility where she lived while blind, weak, and heavily medicated. ${ }^{285}$ She had also been adjudicated incompetent ten months after the will's execution. ${ }^{286}$ There was conflicting evidence from both experts and lay witnesses, and the bequest to the facility represented a change from prior estate plans. ${ }^{287}$ Avoiding a lengthy contest, however, the court resolved the case by relying on an expert

283. See Pamela Champine, Expertise and Instinct in the Assessment of Testamentary Capacity, 51 VILL. L. REV. 25, 27 (2006) (stating that "a probate procedure that offered individuals the opportunity to confirm their testamentary capacity during life would eliminate the evidentiary obstacle, and that, in turn, would improve the coherence of the body of testamentary capacity decisions").

284. Id. at $86-87$.

285. 58 Pa. D. \& C. 4 th 533, 534 (Pa. Ct. Com. Pl. 2002).

286. Id. at 546 .

287. Champine, supra note 283 , at 38. 
assessment of capacity conducted at the time of the will's execution. ${ }^{288}$ Pamela Champine proposes an antemortem capacity test in her article on the subject. ${ }^{289}$

Turning to the goals of undue influence, a properly administered capacity test can efficiently protect the elderly from exploitation. A testator who knows her estate, the objects of her bounty, and the meaning of executing a will should be allowed to dispose of her property as she wishes at the time. Indeed, a competent testator who changes her mind in the last years or months of her life about her testamentary dispositions should not create grounds for a will contest. Capacity should be the only determination regarding the will's validity. Because we value testamentary intent, we should give as much credence to the changed wishes of the testator in the last period of life as we do to intent she had expressed beforehand over the long term. Under any notion of free will-which we say we value here-people can change their minds. A capacity test will determine whether the testator was competent to form the changed intent; this is the only determination necessary.

A good illustration of this principle is the case of Reid. ${ }^{290}$ Reid's capacity was not at issue in the case. The court found the deed, will, and power of attorney invalid on the grounds of "undue influence, overreaching, breach of a fiduciary relationship, breach of an attorneyclient relationship, [and] breach of a position of trust." 291 As previously discussed, the record was replete with evidence that Mary Lea Reid knew exactly what she was doing when she adopted Cupit, deeded him her land, and favored him in her will. If a capacity test had been the sole determination of validity, these gifts would have withstood challenge.

Perhaps there is cause to worry, however, about cases that are less clear, in which capacity is harder to disprove, but in which it nonetheless seems that diminished capacity has led to a distortion of the testator's intent. Undue influence, one could argue, provides a safety valve which would reassure a testator that any future mental decline would not harm genuinely intended beneficiaries. It might capture a middle ground where someone cannot be deemed incapable of looking after oneself but may still have diminished abilities to navigate legal relationships. If this is the case, however, why do we require an extremely low level of capacity for the execution of a will in the first place? The mental

288. Id. Another case in which a will contest was resolved by contemporaneous expert capacity assessment, cited by Champine, is Baun v. Estate of Kramlich, 667 N.W.2d 672 (S.D. 2003).

289. Champine, supra note 283, at 73-93.

290. In re Estate of Reid, 825 So. 2d 1, 4 (Miss. 2002).

291. Id. at 3. 
capacity required for a valid will is lower than that necessary to sign a contract; only marriage requires less. ${ }^{292}$ This minimal requirement, in fact, suggests the opposite of the need for the safety valve of undue influence; it suggests that the tradition of common law wills rightly puts the presumption on the side of valid intent, and that once minimal capacity has been proven, the inquiry ends.

\section{B. Duress}

Duress is a second doctrine that offers relief without the ambiguity and unfairness of undue influence. ${ }^{293}$ As one court discussed, duress is "the gross, obvious and palpable type of undue influence which does not destroy the intent or will of the testator but prevents it from being exercised by force or threats of harm to the testator or those close to him." 294 American wills law has folded the law of duress into the law of undue influence, often classifying it as a species of the latter. ${ }^{295}$ This is unfortunate. Duress, defined by the Restatement, is a wrongful act that coerces a testator into making a bequest he would otherwise not have made. $^{296}$ According to the Restatement, a wrongful act is one that is either "criminal or one that the wrongdoer had no right to do."297 Thus, as Ronald Scalise points out, a " "threat to abandon an ill testator" might constitute undue influence, but it would not qualify as duress (unless the case involved a duty of care on the part of a relative). ${ }^{298}$

\section{Fraud}

Another doctrine that would address these cases is fraud. A significant number of will contests brought under undue influence actually boil down to fraud cases. For example, in In re Estate of Vick, one of the daughters of a large family convinced the mother, contrary to fact, that the father had willed all the property to the boys and left

292. See, e.g., 79 AM. JUR. 2D Wills $\S 67$ (2007) (noting that some courts require a higher degree of mental capacity to execute a contract or deed than for a will); 4 AM. JUR. 2D Annulment of Marriage $\S 29$ (2007) ("A marriage of a person incapable of contracting for want of understanding is not void, but voidable.").

293. For a definition of duress, see DUKEMINIER ET AL., supra note 125, at 191.

294. In re Will of Kaufmann, 247 N.Y.S.2d 664, 682-83 (N.Y. App. Div. 1964).

295. Scalise, supra note 108, at 69.

296. Id.

297. Restatement (ThIRD) OF Property: Wills AND Other DONATIVE Transfers $\S 8.3$ cmt. i (2003).

298. Scalise, supra note 108 , at 69. 
nothing to the girls. ${ }^{299}$ While the court noted this misrepresentation might have been technically "innocent," it also concluded that "[t]here was sufficient evidence for the jury to conclude it was made in reckless disregard of its truth or falsity ... [and that] such statements could hardly be classified 'innocent misrepresentations' made in 'good faith.",300 The court went further, however, and held that even these innocent misrepresentations could provide grounds for setting aside a will because "'one who has obtained unfair advantage by a falsehood ought not to be permitted to retain it, even if he was acting in good faith when he made such statement.","301 As such, the court contrasts such innocent misrepresentation by a beneficiary to mistake of extrinsic fact made by a testator, noting that the latter is generally not grounds for invalidating a will. ${ }^{302}$ This court wove misrepresentation into the undue influence doctrine by explaining that a false representation is a way of exercising undue influence, ${ }^{303}$ but such a blurring of distinctions is unnecessary. Separating the misrepresentation component from undue influence to void wills when there is concrete evidence of misrepresentation would reduce the number of cases to those that could be easily decided, and eliminate many based on vague suspicions that waste the court's time. Another example appears in In re Burke, wherein there was evidence to show that an elderly testator changed his dispositions due to misrepresentations by his caretaker that his attorney of twenty years was trying to cheat him. ${ }^{304}$ Similarly, in Orton v. Gay, the Alabama Supreme Court voided a deed by a mother to her daughter, where the mother alleged that her daughter misrepresented to her that if she did not convey the property to her she would be ineligible for "old age benefits" and would lose most of her estate to inheritance taxes. ${ }^{305}$ The trial court had voided the deed on undue influence grounds based on evidence of the daughter's misstatements and the mother's understandable trust in those statements. ${ }^{306}$

Some might argue that these doctrines - fraud and duress, at leastare susceptible to the same misuse and subjectivity that I have shown to prevail in the application of undue influence. This is unlikely: the elements of fraud and duress are more specific and concrete than those of

299. In re Estate of Vick, 557 So. 2d 760, 766 (Miss. 1989).

300. Id. at 768-69.

301. Id. at 768 (quoting 1 Bowe-PARKER, PAGE ON WILlS $\S 14.1$ (rev. ed. 1960)).

302. Id.

303. Id.

304. 441 N.Y.S.2d 542, 550 (N.Y. App. Div. 1981).

305. 231 So. $2 d$ 305, 308 (Ala. 1970).

306. Id. at 311 . 
undue influence. The elements of fraud are: (1) a misrepresentation of a material fact, (2) intent to deceive, (3) reliance upon the misrepresentation by the party deceived, and (4) resultant injury. Duress involves force or coercive threats that are intended to and do invalidate the victim's free choice. "Misrepresentation of a material fact" is an objective inquiry, as are the other elements of fraud. The "force or coercive threats" of duress must reference otherwise tortious conduct. Although these implicate the notion of free choice, both fraud and duress require specific acts, not merely ill-defined attempts to influence. Thus, neither alternative suffers from the dangers attendant to the doctrine of undue influence.

\section{Tortious Interference with Expectancy}

Tortious interference with expectancy is a tort and must be brought in civil court. ${ }^{307}$ Where the action is judicially crafted, its elements, with minor variations, consist of (1) reasonable certainty of the devise, (2) interference with the expectancy, (3) independently tortious means used to interfere, and (4) harm. ${ }^{308}$ Most states that do recognize this tort include undue influence in the "tortious means" used to divert the inheritance. $^{309}$ They may also include some combination of duress, fraud, threats, coercion, abuse of fiduciary duty, forgery, destruction, or suppression of a will. ${ }^{310}$ Removing undue influence from the enumerated means by which to satisfy this tort, yet leaving the tort standing, would have the same beneficial effect I have argued for in will contests, without impairing this tort's effectiveness.

One of the advantages of this tort's nonprobate status is that this cause of action can reach more assets than a probate action and may more adequately compensate the injured party and punish the transgressor because a civil court can award damages. ${ }^{311}$ If a contested will is simply denied probate, on the other hand, the estate will most likely pass by intestacy, which may do little more than the will itself to

307. As of this writing, the following states recognize this tort: Florida, Illinois, Indiana, Iowa, Maine, Massachusetts, Missouri, New Mexico, Pennsylvania, Texas, West Virginia, and Wisconsin. See Steven K. Mignogna, On the Brink of Tortious Interference with an Inheritance, 16 PROB. \& PROP. 45, 45 (2002).

308. Id. at 46 .

309. See, e.g., Labonte v. Giordano, 687 N.E.2d 1253, 1255 (Mass. 1997); DesMarais v. Desjardins, 664 A.2d 840, 843 (Me. 1995); Cardenas v. Schober, 783 A.2d 317, 325 (Pa. 2001).

310. Diane J. Klein, The Disappointed Heir's Revenge, Southern Style: Tortious Interference with Expectation of Inheritance-A Survey with Analysis of State Approaches in the Fifth and Eleventh Circuits, 55 BAYLOR L. REv. 79, 85 (2003).

311. Id. at $88-89$ 
carry out the testator's intent. As a tort, this cause of action allows for both compensatory and punitive damages, which are paid out of the defendant's assets, not those of the estate. ${ }^{312}$ Moreover, as a tort, litigants may have access to federal forums under diversity, unlike probate actions from which federal courts usually abstain under the probate exception. Importantly, then, unlike a probate claim, a tort claim requires the defendant to answer. ${ }^{313}$

The statute of limitations for filing an intentional interference claim should remain quite short, as it is in most states that recognize the tort. ${ }^{314}$ Allowing this tort should in no way undermine the policy goal of expeditious settling of estates. At this point, probate courts in many states lack jurisdiction to hear such claims. ${ }^{315}$ Indeed, many states that do recognize the tort nevertheless require the contestant to exhaust probate remedies before turning to a civil court with an intentional interference claim, or to show the lack of adequate remedies in a probate action. ${ }^{316}$ The logic in this regard is that damages are an element of the intentional inference claim, and until the probate court has rendered a decision in the will contest, there is no basis for damages.

Most importantly, however, tortious interference with expectancy differs from an action in a will contest in that it shifts the focus, to some extent, from the testator to the beneficiary and the alleged tortfeasor. ${ }^{317}$ This shift has the significant advantage of turning attention from the state of mind of the deceased to that of living parties. ${ }^{318}$ Shorn of the troubling element of undue influence, such an inquiry is much easier to conduct and much more likely to arrive at some colorable claim to the truth by searching only for independently tortious conduct.

Finally, there are particular contexts in which this cause of action is uniquely suited to the inheritance issues at stake. One commentator, for example, has argued that this is the case in the family farm, ${ }^{319}$ but the argument is equally applicable to other family held businesses as well.

\footnotetext{
312. Id. at 89 .

313. Id. at 88 .

314. See, e.g., In re Estate of Ellis, 887 N.E.2d 467, 469 (Ill. App. Ct. 2008) (ruling that intentional interference claims were subject to the same statute of limitations that the Probate Code establishes for all will contests).

315. See, e.g., Hamblin v. Daugherty, Nos. 06CA0109-M, 06CA0112-M, 2007 WL 3243379, at *6 (Ohio Ct. App. Nov. 5, 2007).

316. See, e.g., id.; Gianella v. Gianella, 234 S.W.3d 526, 530 (Mo. Ct. App. 2007); Schilling v. Herrera, 952 So. 2d 1231, 1236 (Fla. Dist. Ct. App. 2007).

317. Klein, supra note 310 , at 88 .

318. Id.

319. Marianna R. Chaffin, Stealing the Family Farm: Tortious Interference with Inheritance, 14 SAN JOAQUIN AGRIC. L. REV. 73, 74 (2004).
} 
Such entities are susceptible to plunder or misdirection of assets while the testators are still alive, depredations which can interfere with other siblings' inheritance.

As of this writing, fewer than half the states recognize a cause of action for tortious interference with expectancy. ${ }^{320}$ Perhaps the most famous of the cases brought under this claim has been Marshall $v$. Marshall, in which Vickie Lynn Marshall, better known as Anna Nicole Smith, sued the son of her late husband, Texas oil billionaire J. Howard Marshall, on the grounds that the son had tortiously interfered with several inter vivos gifts to Anna. ${ }^{321}$

Many reasons support keeping, and indeed expanding, recognition of this cause of action once shorn of the unhelpful undue influence element. Most importantly, by requiring that the plaintiff show a reasonable certainty that he would have received the devise, the tort seems likely to do away with the plethora of cases brought by disappointed children who show up for a will contest after having lost contact with the testator for years. This claim has other deterrents to baseless cases as well. In probate, the estate pays the court costs of will contests, but in a civil case, the parties pay-leaving open the possibility of a court punitively shifting costs to a party who brought a baseless case. From the opposite perspective, in cases of egregious conduct interfering with an inheritance, a civil court provides remedies that a probate court does not, such as punitive damages and consequential damages. These damages could cover such harms as emotional distress. In some situations, a probate court offers little deterrence to a would-be manipulator of a testator's bequests. A sibling, for example, who illicitly procures a testamentary disposition, may still get a share if the will is found invalid in favor of intestacy. A civil court, by contrast, has more latitude to effect a remedy which can take the misconduct into account. Also, there are circumstances in which a probate court cannot provide adequate remedy, such as the malicious destruction of a will, the discovery of fraud after the end of the probate period, or the tortious inducement of an inter vivos transfer. ${ }^{322}$ In sum, allowing a civil action for intentional interference with expectancy without an undue influence component might prove to be a bracing tonic against the proliferation of wasteful wills litigation, as well as an effective deterrent for serious cases of tortious action.

320. See Mignogna, supra note 307.

321. Marshall v. Marshall, 275 B.R. 5, 7, 9 (C.D. Cal. 2002).

322. Gianella v. Giannella, 234 S.W.3d 526, 530 (Mo. Ct. App. 2007). 


\section{AdDRESSING ELDER FinANCIAL AbuSE Through CRIME SOlVING AND STRICTER WILL EXECUTION REQUIREMENTS}

One reason for the persistence of undue influence is the notion that the doctrine protects vulnerable elderly from exploitation by unscrupulous caretakers and acquaintances. Concern is justified: although statistics are elusive, financial abuse of the elderly is widespread. ${ }^{323}$ One study estimates that about forty percent of reported elder abuse cases concern financial exploitation. ${ }^{324}$ Moreover, a vast sum of money is at stake: the current generation of elderly will make "the largest intergenerational transfer of wealth in American history." 325 The undue influence doctrine, however, fails to protect the elderly in any significant way, and at times undermines their testamentary freedom even further. If financial elder abuse is such a concern, there are at least two more effective ways to address it: better crime detection and stricter execution requirements.

\section{A. Undue Influence Doctrine Does Not Protect the Elderly}

In an attempt to codify undue influence, section 21350 of the California Probate Code disqualifies seven categories of people from receiving donative transfers by testamentary instruments, including the category at issue here: a "care custodian of a dependent adult who is the transferor." 326 The California Welfare and Institutions Code, in turn, defines "care custodian" by supplying a list of relevant agencies and people, and then goes on to include "any other... agency or person providing health services or social services to elders or dependent adults." 327 This attempt to codify undue influence in fact shows how useless and harmful the doctrine is.

In Bernard v. Foley, the California Supreme Court ruled that the term "care custodian" included close and long term friends who provide significant care over a long period of time. ${ }^{328}$ Although the California

\footnotetext{
323. See generally Wasik, supra note 6 , at 77 .

324. Id. at 77,78

325. John Leland, Breaking the Silence, N.Y. TIMES, Mar. 18, 2008, at H1. Experts predict that even after estate taxes, this generation of beneficiaries will receive between twenty-four and sixtyfive trillion dollars between 1998 and 2052. John J. Havens \& Paul G. Schervish, Why the \$41 Trillion Wealth Transfer Estimate is Still Valid: A Review of Challenges and Comments, 7 J. GIFT PLAN. 11, 12 (2003).

326. Cal. Prob. Code $\S 21350$ (West Supp. 2009).

327. CAL. WELF. \& INST. CODE $§ 15610.17$ (West 2001).

328. Bernard v. Foley, 139 P.3d 1196, 1204 (Cal. 2006). Earlier cases decided under this statute
} 
Law Commission, at the behest of the state legislature after this decision, suggested redefining "care custodian" to exclude personal friends who care for an elder without compensation. Foley highlights the way the doctrine still impairs testamentary freedom, lacks protection for elders, and constitutes bad public policy. Further, the proposed revisions fail to address these concerns.

In Foley, an elderly widow amended a testamentary trust shortly before she died to give the couple who had cared for her, Foley and Erman, each a fifty percent residuary interest. ${ }^{329}$ The testator's extended family - she had no children - contested the amendment to the trust on the grounds that the couple was disqualified from the bequest under section 21350(a)(6) as "care custodians," and did not fall under any exception to the statute. ${ }^{330}$ The trial court found insufficient evidence to establish the "business relationship" necessary to the definition of "care custodian," but the appellate court reversed, finding that Foley and Erman were "care custodians" under the statute and that, as such, they had failed to rebut the presumption of undue influence that the designation created. ${ }^{331}$ The supreme court granted proponents' petition for review. ${ }^{332}$

The California Supreme Court concluded that Erman and Foley did, in fact, fall within the "care custodian" category in the statute. ${ }^{333}$ Foley and Erman argued that the term "services" implied compensation, which they had not received. ${ }^{334}$ The court, however, based its reasoning on another part of the California Welfare and Institutions Code, which states that "care custodian' means an administrator or an employee of the following public or private facilities or agencies, or persons providing care of services for elders or dependent adults, including members of the support staff and maintenance staff [of the listed facilities]." 335 The court reasoned that the word "or" in the statute made clear that the legislature did not mean to exclude "uncompensated or nonprofessional" providers, and thus the care Erman and Foley gave Bosco fell under the statute's

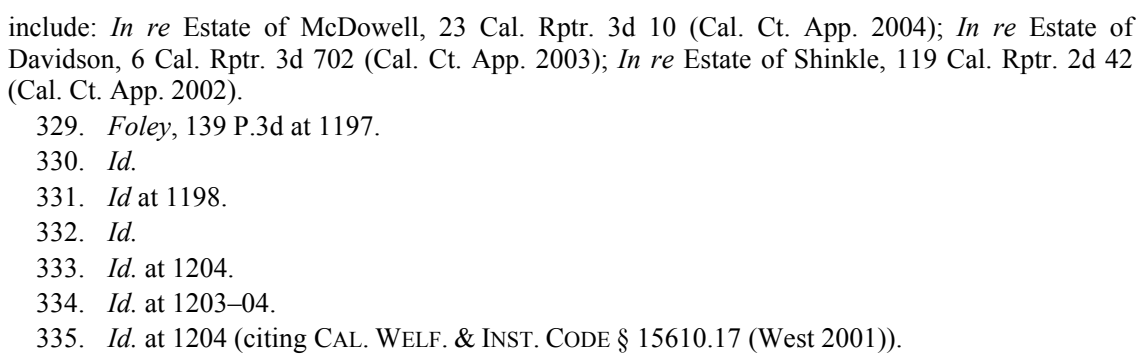


prohibition. $^{336}$ For reasons which are unclear, Erman and Foley did not try to rebut the undue influence presumption which then arose. ${ }^{337}$

A number of problems arise upon perusal of the decision. Its upshot seems to be that those who provide care to the elderly out of friendship and emotional connection are prevented from being the object of that person's bounty unless they can rebut the presumption of undue influence, which creates a heavy evidentiary burden. On the other hand, what more natural object of the testator's bounty could there be than those who cared for her in a final illness, with all that that implies? Some of the services that Erman and Foley provided for Bosco, who lived with them for the two months before her death, without compensation, were as follows:

Foley did decedent's grocery shopping, prepared some meals for her and occasionally attended to her personal needs, including helping to change the diapers she wore. Foley also made decedent's bed and assisted her with bathing. He applied topical medications to decedent's body, sometimes with Erman's assistance.... Erman prepared meals for decedent, spent every day with her, assisted her in getting to and from the bathroom, helped her into bed, fixed her hair, cleaned her bedroom and did her laundry.... washed [her] face and hands... administered oral medications to decedent ... helped decedent apply ointments to a rash that had developed in her intimate areas. Erman also cared for decedent's wounds, applying salves and antibiotics to sores on her legs and thereafter bandaging those areas. ${ }^{338}$

How many of us would be willing to perform these services, with or without compensation? Moreover, it is clear from the above record that Bosco received emotional care from Erman and Foley as well: Erman spent her days with her, brushed her hair and washed her face in preparation for the day, made sure Bosco got out of bed and looked presentable. ${ }^{339}$ Bosco was hardly neglected or treated in a mercenary manner, as if Erman and Foley were merely waiting for her to die so they could collect. ${ }^{340}$ Reading between the lines, it seems likely that Bosco enjoyed respect, humanity, companionship, and comfort during her last illness.

\footnotetext{
336. Id.

337. Id. at 1209.

338. Id. at 1202.

339. Id.

340. Bosco executed the seventh amendment to her trust, the one benefiting Erman and Foley, three days before she died. $I d$. at 1197.
} 
Ironically, it is exactly the intimate and extensive nature of the care Erman and Foley gave Bosco that the court interpreted to place them under the statute. It observes, after the above quoted litany, that "both Foley and Erman provided substantial, ongoing health services to decedent while, at the end of her life, she was residing in their home and it was during this period that decedent amended her trust to [benefit them]." ${ }^{341}$ The court relied heavily on the fact that the proponents administered medication, including morphine, and tended to "wounds," tasks which "could be performed by a nurse"-and so, presumably, they reached a level of care constituting "services" under the statute. ${ }^{342}$ Such ministrations, however, in these days of managed care, are often performed by non-professional family members of the ill person; diabetics routinely administer their own insulin shots. It is hard to see what crucial difference these few low level medical tasks made to the case. In fact, Bosco seems to have received ideal care for an elder in her position. Ill and dependent on others, she found as caretakers personal friends who truly cared for her and gave her companionship and comfort as well as physical aid. This is all we as a society could hope for our elders, and it seems fair and understandable - as opposed to suspiciousthat the elder would want to compensate those who cared for her. ${ }^{343}$

The court looked to the legislative history of the statute and public policy to justify its conclusion, largely unconvincingly. It noted that the law was a response to accounts of an attorney who had drafted wills for many old age facility residents to benefit himself or his law partners, and that the care custodian language was a later amendment. ${ }^{344}$ The later amendment was motivated by, in the words of the legislative committee, the existing law's failure to "provide a presumption of invalidity ... to practical nurses or other caregivers hired to provide in-home care." 345 Despite the committee's clear use of the word "hired," the California Supreme Court insisted that the bill was "obviously not restricted to paid caregivers" because a later section of the report noted that "care custodians are often working alone and in a position to take advantage of the person they are caring for." 346

\footnotetext{
341. Id. at 1202 .

342. Id. at $1202-03$.

343. David Horton makes the same point. Horton, supra note 6, at 69 (noting that "a senior could very well want to reward a caregiver for his or her efforts but be unable to do so during life").

344. Foley, 139 P.3d at 1205

345. Id. at 1206 (citations omitted).

346. Id.
} 
The proponents' arguments in Foley deserve attention because they bolster much of my point about undue influence doctrine and its impositions on testamentary freedom. They also suggest why the law commission's revisions to the statute serve little purpose. As the dissent pointed out, "it seems unwise to penalize Good Samaritans by making them less eligible to receive the gratitude to those they help, the kinder they have been." 347 Indeed, Erman and Foley were precluded precisely because the care they provided was of a substantial and ongoing nature: nothing in the statute would prevent someone who offered "trivial or undependable care" from inheriting. ${ }^{348}$ The dissent also notes that the statute creates what should be a narrow exception to testamentary freedom $^{349}$ - and one, I argue, that should not exist at all.

Based on the above, the law commission's suggested revisions to the statute make little improvement. Its rationales for keeping the "care custodian" clause are as follows: (1) caregivers have the opportunity to exercise undue influence, (2) elders depend on caregivers, and (3) gifts to caretakers are the inherent result of overreaching. ${ }^{350}$ As David Horton points out, however, it is unclear why a gift to a caregiver would be suspect. ${ }^{351}$ Why should elders be denied the freedom to reward the caretakers who tended to their most intimate needs and provided them with care and companionship in their time of weakness and decline? ${ }^{352}$ How bad would it be if such a caregiver contemplated the possibility of reward? The revised statute, by presumptively barring compensated caretakers from inheriting, encroaches on the freedom of the dependent elder to make a gift to someone who cared for her. The Foley majorityand the state law commission-seem to live in an illusory land of altruism which bears little relationship to the real world of complex and multifaceted motivations which drive most people. The court prissily observes that a caregiver who thought about reward would be one "with designs on ... the elder's future estate... precisely the situation the [statute] was meant to address." 353 The dichotomy between self-interest and altruism, however, bears examination. Does it follow that a

\footnotetext{
347. Id. at 1214 (Corrigan, J., dissenting).

348. Id.

349. Id. at 1215.

350. Horton, supra note 6 , at 49 .

351. Id.

352. Home caregivers, exempt from federal minimum wage and overtime laws, earn an average of $\$ 20,283$ per year and provide such services as inserting catheters, changing diapers, handling oxygen tanks and wheelchairs, and ministering to people with chronic illnesses who often have a dozen doctors attending to them. Id. at 47 (citations omitted).

353. Bernard v. Foley, 139 P.3d 1196, 1209 (Cal. 2006).
} 
caregiver's ministrations are harmful or inadequate-or morally wrong - because it occurs to the caregiver that they might result in future gain? Indeed, might it not be the case that a financially interested caregiver is exactly the kind of person we would want to care for an elderly person? Why, conversely, is an elder's change in estate plan to benefit such a caregiver, if made with certified capacity, automatically suspect? As the appellant in Reid pointed out, dependence is in the eye of the beholder: "[m]isconstruing the fact that Mike Cupit was dependable in attending to the needs of his adoptive mother, the Chancery Court found that she was sufficiently dependent on him that a confidential relationship existed" and that Cupit exercised undue influence on Reid. ${ }^{354}$ Thus, the Code's caregiver provisions, like undue influence case law, ignore the reality of the care elders receive from those who supposedly "unduly influence" them.

\section{B. Institute Better Crime Prevention}

The FBI has no category in its Uniform Crime Reporting System for elder financial abuse. ${ }^{355}$ Police and prosecutors lack training to investigate elder abuse when it is reported, and often refuse to investigate under the pretext that it is a civil matter. ${ }^{356}$ A high percentage of those who commit financial crimes against the elderly are family members, ${ }^{357}$ and yet this is the one category of beneficiary absent from the California statute. One official who prosecutes such cases asserted, "the majority of financial abuse cases involve adult children who often neglect their parents. ... The caregiver [who commits financial abuse] tends to be an available out of work child with a substance abuse or gambling problem." 358 This is not to say that caretaker abuse by non-relatives is rare, but the law's presumption that leaving money to a family member is somehow "natural," and above suspicion, is a product of what we wish to believe rather than of reality. Indeed, an elder's move to a nursing home may enable further plundering by family members, who are now in control of the elder's material goods. ${ }^{359}$ In some ways, exploitation by family members may be even less likely to be reported than other forms of abuse. Often emotional bonds and the wish to protect their children

354. Brief of Appellant, supra note 219, at 23 (emphasis added).

355. Wasik, supra note 6 , at 77-78.

356. Id.

357. Id.

358. Id.

359. Id 
prevent the victim from reporting the abuse. ${ }^{360}$ Measures that addressed these lacuna, such as creation of an FBI database category for these incidents and better training of police and prosecutors, would go much farther in reducing this kind of crime.

Further, procedures that specifically assess the validity of wills signed by elders under suspicious circumstances would be much more effective than after the fact will contests in safeguarding an elder's testamentary intent. For example, addressing the issue of capacity at the time the will is signed would resolve a large percentage of these cases before they even begin. ${ }^{361}$ State law should allow for any testator worried about a will contest, or worried about her future loss of capacity, to arrange for certification by a special process. Such a process would involve examination by an independent psychiatric specialist to determine capacity. A will executed under such validation would be virtually immune to attack, even on capacity grounds. Many European countries and some American states ${ }^{362}$ have instituted exactly this measure: the officials responsible for the validation are called "super notaries." determining the testator's mental capacity, advising the testator on the legal implications of her decisions, and ultimately authenticating the document. $^{364}$ A super notary's authentication certifies that the document is free of undue influence or fraud. ${ }^{365}$ These services make will contests extremely cumbersome, expensive, and, therefore, unlikely. ${ }^{366}$ In France, impeaching the authenticity of a document signed by such a notary is "tedious and costly." 367 If the challenger fails, he is "subject to heavy civil damages." 368 I am not the first to call for the institution of this kind of notary in the wills process. Lloyd Bonfield has done so as well, suggesting that we should adopt a means "by which a perfectly executed

360. Id

361. Champine, supra note 283, at 93.

362. Arkansas, Ohio, and North Dakota have super notary statutes. See Langbein, supra note 5, at 2044.

363. See Reina, supra note 255 , at 814 (recommending the adoption of super notaries in the United States to "alleviate the will contest issues that arise from the manipulation of the doctrine of undue influence"); see also Langbein, supra note 5, at 2044 (commending the continental system of will authentication by super notary as a "valuable defensive device for a testator who fears a will contest").

364. See Reina, supra note 255, at 810-11 (stating French "notaires" draft wills, real property transactions, and company formations).

365. Id. at 806

366. Id. at 810 .

367. Id.

368. Id. 
will can be immunized from the challenge of disgruntled heirs on the ground of undue influence." 369

Thus, a will's certification by a super notary would assuage some of the concerns undue influence addresses without replicating its harms. A super notary would not be able to reform a will based on her biases about appropriate beneficiaries because her sole mandate would be to determine that the named beneficiaries were truly the ones the testator intended. Would the institution of super notaries make will execution more expensive? Perhaps, but a testator with few resources likely will not attract a will contest. The testator who needs the added assurance of this form of attestation is probably also one who can afford it.

\section{VII.ESTABLISHING PRIORITIES; INSTITUTING FORCED HEIRSHIP}

If we care as much as practice indicates about keeping wealth in families, why not simply make it illegal to disinherit immediate family, as is the case in many European countries, which either impose forced shares or grant judicial discretion to override a will and order family maintenance? ${ }^{370}$ If family protection is a goal on par with testamentary freedom, this seems like a logical and more efficient way to achieve it. If, as most people in the field agree, such proposals are sure to fail, ${ }^{371}$ then let us agree that we value testamentary freedom more than protecting families, and abolish undue influence as a way to protect it.

Most European countries have some form of forced heirship. Swedish law, for example, deems invalid any will that leaves so much of an estate to third parties that the children retain less than they would have received under intestacy. ${ }^{372}$ Similarly, in Finland, a lineal descendant is entitled under the law to half of what she would have received under

369. Bonfield, supra note 97, at 1919.

370. Deborah Batts, I Didn't Ask To Be Born: The American Law of Disinheritance and a Proposal for Change to a System of Protected Inheritance, 41 HASTINGS L.J. 1197, 1198 (1990).

371. Champine, supra note 283, at 93 (noting that calls for fixed share legislation have gone unheeded). But see Batts, supra note 370, at 1197; Ralph C. Brashier, Children and Inheritance in the Nontraditional Family, 1996 UTAH L. ReV. 93 (1996); Ralph C. Brashier, Disinheritance and the Modern Family, 45 CASE W. RES. L. REV. 83 (1994) [hereinafter Brashier, Disinheritance and the Modern Family]; Chester, supra note 282; Paul G. Haskell, The Power of Disinheritance: A Proposal for Reform, 52 Geo. L. REV. 499 (1964); Helene S. Shapo, "A Tale of Two Systems:" Anglo-American Problems in the Modernization of Inheritance Legislation, 60 TENN. L. REV. 707 (1993); Katherine Shaw Spaht, Forced Heirship Changes: The Regrettable Revolution Completed, 57 LA. L. REV. 55, 57 (1996) (admitting to a "bias in favor of forced heirship" and condemning the Louisiana legislature's curtailment of the regime in that state); Tamara York, Protecting Minor Children from Parental Disinheritance: A Proposal for Awarding a Compulsory Share of the Parental Estate, 1997 DET. C. L. REV. 861, 864.

372. Batts, supra note 370. 
intestacy. ${ }^{373}$ Spain, Greece, Switzerland, and Scotland give lineal descendants similar protections. ${ }^{374}$ The advantages of replacing undue influence cases with a system of forced heirship are obvious: the law would be clear, it would protect heirs without completely depriving the testator of freedom to dispose of property, it would remove all the ambiguity, inconsistency, and arbitrariness of the law this Article has documented, and it would prevent deprived heirs from needing state support. ${ }^{375}$ These laws allow a testator to will a significant portion of his estate - often half - as he wishes, either to third parties or to a favored child, thus preserving a large element of testamentary freedom. ${ }^{376}$

Even Great Britain, with its long common law tradition of protecting testamentary freedom, has systems in place to protect spouses and children from disinheritance. ${ }^{377}$ England, for example, allows the testator's children to claim "reasonable financial provision" from the estate. ${ }^{378}$ Not only does English law allow spouses and children to make this claim, it also allows for such claims on the part of anyone whom the decedent treated as a child during any of decedent's marriages, anyone who was being maintained by decedent immediately prior to death, or a former spouse who has not remarried. ${ }^{379}$

Other countries go further than Great Britain. China, for example, in an attempt to reform its welfare system, instituted inheritance laws which reward heirs for supporting the decedent during his or her lifetime, whether the estate passes through will, intestacy, or contract. ${ }^{380}$ In sharp contrast to United States law, the Chinese law of wills regards caregivers, whether related to the decedent or not, as "natural object[s] of the decedent's bounty." 381 American spouses can usually claim an elective share, of course. In Uniform Probate Code states, the share is a graduated amount depending on the length of the marriage, maxing out after fifteen years, when the spouse can claim the maximum of fifty

\footnotetext{
373. Id. at 1212 .

374. Id. at 1213 .

375. Id. at 1223 .

376. Id. at 1228 .

377. Ralph C. Brashier, Protecting the Child from Disinheritance: Must Louisiana Stand Alone?, 57 LA. L. REV. 1, 18 (1996).

378. Id. at 24 .

379. Brashier, Disinheritance and the Modern Family, supra note 371, at 123.

380. Frances H. Foster, Linking Support and Inheritance: A New Model from China, 1999 WIS. L. REV. 1199, 1241.

381. Id. at 1245.
} 
percent. ${ }^{382}$ Why not broaden these protections if they matter to us as a society?

The question comes down to the one Ray Madoff posed: how much do we care about keeping wealth in families as a matter of right? ${ }^{383}$ If we care about such a policy, let legislatures codify it through a system of forced heirship, rather than leaving courts to implement it by default. If we care about the elderly and are prepared to be honest about the lives many of them lead in our society, let legislatures pass laws that allow for the effective investigation and prevention of crimes against them. Because undue influence is based on inaccurate psychological premises and fails to achieve the goals we as a society agree on, it is time to abolish it.

Finally, I return to Lakatosh. If the doctrine of undue influence is abolished, would scenarios like this one proliferate and create significant injustice? I argue they would not; or rather, that the injustice we may perceive in such cases is outweighed by the harm of continuing to use the undue influence doctrine to invalidate wills. The harm to Rose Lakatosh-stealing her money and depriving her of her means of support-occurred during her lifetime, and was remedied during her lifetime by her revocation of the power of attorney without need of undue influence. The money stolen could have been placed in a constructive trust, which in fact, it eventually was. The harm after her death was to her relatives, who were deprived of an expected inheritance. Why should we care much about them? They had abandoned Rose, left her to live in "squalor and filth," without electricity, as easy prey to a stranger who gave her companionship and helped her around the housewho, in her words, "saved her life." "384 Had any of them been present in her life in a meaningful way, it is doubtful Jacobs would have been able to embed himself as deeply as he did. Do we wish to punish Jacobs because he cared for Rose or because he stopped doing so?

Many cases like this, upon examination of the complete record, lose their moral and legal clarity. Still, some elderly people - often, but not always, women - are influenced in a way that makes us less than sure about their testamentary intent, yet the influence falls short of outright duress or fraud. For example, an older person may refuse to move closer to adult children, constraining their oversight and ability to guard against the unscrupulous. Such cases, if undue influence were to be abolished,

382. UNIF. PROBATE CODE $§ 2-201$ (amended 1990).

383. Madoff, supra note 5, at 624 .

384. Estate of Lakatosh, 656 A.2d 1378, 1382, 1385 (Pa. Super. Ct. 1995). 
would perhaps not be brought. Given that, as I hope I have shown, the number of these cases is small, how harmful would this be?

It is harmful if we are concerned with keeping wealth in families. Since these are will cases, the testator has not given away any means of subsistence, so we have no worries on that score. As most often happens, undue influence cases are brought, and won, by blood relatives disinherited in favor of someone who befriended and cared for the testator later in life. Often, the disinherited are relatives who had neglected or abandoned the testator and appeared only for the will contest. These examples should not trouble us. Another possible harm is making the testator worry about future interference with her intent- the super notary system would offer a remedy for this.

There are, of course, still cases in which it appears that a finding of undue influence did prevent injustice and save someone-usually an elderly person-from exploitation. Many such cases could be adjudicated on other grounds, such as fraud and outright duress, but ultimately some, without the doctrine, would leave an injustice unremedied. What of the faithful relatives routed by a true miscreant, who plays upon an elder's fears, cuts them off from family, or worse? This offends our sense of justice only if we think it is unjust to devise wealth to non-relatives. After all, one has a right to leave one's estate to anyone. And unless a contract was involved there was no bargained for assurance or justified reliance on the part of the relative of gaining the inheritance. In arguing for the abolition of the doctrine, I assert that it is acceptable that these few cases would fail to be brought given the countervailing benefits of its abolition.

\section{VIII.CONCLUSION}

In conclusion, then, let us decide what we care about and effectuate it openly, rather than letting juries and courts enforce one set of standards while purporting to maintain another one. If children-minor or notdeserve protection from disinheritance, legislatures should enact laws that protect them. If a testator's intent should override these concerns, let courts enforce such intent. In either case, it is time to abandon this doctrine. 